\title{
The International Monetary Fund, the World Bank and Financial Stability: The Case of Russian and East Asian Financial Crises
}

\author{
Aikaterini C. Valvi ${ }^{1}$, Konstantinos C. Fragkos ${ }^{2}$ and Christos C. Frangos ${ }^{3}$ \\ ${ }^{1}$ Department of Management, Birkbeck, University of London, UK \\ ${ }^{2}$ Division of Medicine, University College London, UK \\ ${ }^{3}$ Department of Business Administration, Technological Educational Institute (TEI) of Athens, Greece
}

\begin{abstract}
The role of the International Monetary Fund (IMF) and the World Bank (WB) in providing financial stability to countries with financial problems has received conflicting views from different social and political groups. The purpose of this paper is to examine whether these two international organizations provide financial stability by focusing on the case of the Russian and East Asian financial crises. After a comprehensive analysis (graphs, tables and statistical regression models), the researchers found that the support of both the IMF and the WB was mostly without success in these two crises; thus promoting financial instability. This finding comes from both a descriptive analysis of financial stability in terms of unemployment, inflation and changes in GDP and GDP per capita and quantitative calculations by performing multiple linear regressions in PASW 18.0 with certain indicators [GDP Annual growth rate, Interest rate spread (lending rate minus deposit rate, \%), Inflation, GDP deflator (annual \%), Annual industrial value and GINI Index]. The intervention of these international organizations appears to have been followed by unemployment and inflation rises, as a result of their financial policies. These results provide important incentives for international policy changes in dealing with financial crises, emphasizing the importance for less destabilizing practices.
\end{abstract}

Keywords: Financial Stability, International Monetary Fund, World Bank, East Asia

\section{Introduction}

Up to now, there is no single, widely accepted definition of financial stability (FS), and many academics and practitioners have dealt with it from different angles. What makes the definition difficult is the interdependence and the complex interactions of different elements of the financial system among themselves and with the real economy (Djebbar, 2009; Gadanecz and Jayaram, 2009, p. 145). In the literature there are many definitions of $\mathrm{FS}^{\mathrm{i}}$. Essentially, what they all discuss is that 'Financial stability is a condition in which an economy's mechanisms for pricing, allocating, and managing financial risks are functioning well enough to contribute to the performance of the economy' (Schinasi, 2004, p. 4).

The International Monetary Fund (IMF) ${ }^{\mathrm{ii}}$ and the World Bank (WB) are international organizations with multiple member countries set up to regulate the international monetary system and ensure FS for each country member (Polak, 1994).

The IMF is an organization of 187 countries, working to foster global monetary cooperation, secure FS, facilitate international trade, promote high

Copyright (C) 2012 Aikaterini C. Valvi, Konstantinos C. Fragkos,and Christos C. Frangos.This is an open access article distributed under the Creative Commons Attribution License unported 3.0, which permits unrestricted use, distribution, and reproduction in any medium, provided that original work is properly cited. Contact author: Aikaterini C. Valvi E-mail: a.valvi@bbk.ac.uk 
employment and sustainable economic growth and reduce poverty around the world. ${ }^{i i i}$ As originally conceived at Bretton Woods, the IMF was to be a supranational body essentially doing two things: a) it would regulate the rates at which currencies were exchanged among member countries; and b) it would help ensure international stability by making loans at times of crisis in member countries' balances of payments (Peet, 2009, p. 66). In providing financing to its members under various mechanisms and facilities, the IMF almost always engages in 'conditionality'. iv Under conditionality, the IMF disburses money to a borrowing country in doses rather than in full and only if the country can demonstrate that certain economic and financial policies the borrowing country's government committed to in advance with the IMF are in fact being implemented and having the desired results (Head, 2004). Today, IMF policies directly affect the economies of 187 countries and influence the lives of the vast majority of the world's people.

The $\mathrm{WB}^{\mathrm{v}}$ is a vital source of financial and technical assistance to developing countries around the world. Its mission is to fight poverty with professionalism for lasting results and to help people help themselves and their environment by providing resources, sharing knowledge, building capacity and forging partnerships in the public and private sectors (Meltzer, 2006). The main challenges of the WB are focused on: (i) poverty reduction and the sustainable growth in poor countries (e.g. Africa); (ii) solutions to the special challenges of post-conflict countries and fragile states; development solutions for middle-income countries; (iii) regional and global issues (climate change, infectious diseases, trade); (iv) greater development and opportunity in the Arab world; (v) pulling together the best global knowledge to support development.

Until now there is a controversy between governments, which support that the IMF and WB achieve their goals successfully, and thousands of workers and students, who demonstrate against the IMF supporting that in many cases it produces poverty, hardship, starvation as well as economic instability (Peet, 2009, p. 66). The main points of criticism are that it is in effect a 'bad medicine', creating distributional and social injustice and trampling national sovereignty, while its methods include secrecy and opaqueness and may not be totally democratic (Head, 2004). vi In addition, there are many voices mentioning that due to the inherent nature of economy as a social science, many nondeterministic reasons (including politics) seem to play a role in economic phenomena (Soros, 2009). That is, the US as the IMF member with the largest voting quota exerts much more influence on decisions rather than any other country members. So, an issue arises whether financial aid from the IMF and WB to each country is affected from its relationships with the US (Weisbrot et al.,2001).

Hence, the research question under investigation is whether the IMF and the World Bank promote financial stability with their policies and activities. We will focus on financial stability in terms of economic growth, employment indicators and IMF loans. Our general belief is that the IMF and WB seem to cause more financial instability to the countries they aid - in the short term at least - rather than creating for them a safe road towards growth and development (Przeworski and Vreeland, 2000). For our opinions, there are many counterarguments, some of which are discussed in a book by Brau and McDonald (2009) and are briefly described in the Discussion. The reseachersconclude by suggesting certain recommendations for future policies of the IMF and WB, signifying the need to be more flexible.

\section{Examples of Financial Instability}

Until today, a large number of countries have requested help from the IMF and the WB in order to deal with a financial crisis and to avoid the possibility of declaring bankruptcy. In the following pages, I am going to present the unsuccessful support of the two international organizations in the Russian and East Asian financial crises, since their intervention led to rising unemployment and poverty associated with declining GDP growth. 


\section{Russian Financial Crisis}

The Russian Federationvii was founded following the dissolution of the Soviet Union in 1991; currently, it has a market economy with enormous natural resources, particularly oil and natural gas, while it is the 10th largest economy in the world by nominal GDP (Foreign-\&-CommonwealthOffice-UK, 2010). Things were not always like this, especially during the 1990s, when Russia wished to move from a communist economy to an open market.

The West became heavily involved in this transition and it was decided that the IMF and the WB, along with certain other organizations, were the most suitable to coordinate this transition, because of their high economic expertise as well as delicate geopolitical reasons in Russia's relationship with other countriesviii .The researchers will avoid exaggerating rhetoric and use scientific terms to address all issues (Gaidar, 1997). Their view is that the IMF failed in assisting Russia and could have done more, despite the inherent difficulties posed by the Russian domestic political system (Anderson et al., 2000).

\section{Russia and its Cooperation with the IMF: Was the Crisis Written before-hand?}

The IMF and WB's assistance to Russia went through 5 phases (Gould-Davies and Woods, 1999):

- Phase-one:-advice-but-no-money-(1988July-1991)

- Phase-two:-first-attempts-atstabilization-(August-1991-September1993)

- Phase-three:-reform-and-politicalchange-(October-1993-March-1995)

- Phase-four:-stabilization-and-the-rise-ofthe-oligarchs-(March-1995-November1997)

- Phase-five:-the-crash-(October-1997September-1998)
The assistance of both organizations towards Russia began as technical advice in line with the Washington consensus (privatization, stabilization and liberalization), since Russia was granted only associate membership in 1991. In 1992, they became full members and received $\$ 1$ billion support that year and $\$ 3$ billion in 1993, with the conditions of liberalization and stabilization (Woods, 2006). The freeing of prices led to sky high inflation rates (Figure 1) which proved very difficult to decrease and on 19 September 1993, the IMF suspended its loan program towards Russia because of this. The third step of privatization, which took place mainly during phase four, led to the presence of an oligarchic elite which controlled the Russian economy and put obstacles in its growth. This radical reform strategy of restructuring the economy led to high unemployment rates and decrease of GDP to \$395 billion dollars in 1995 from $\$ 516$ billion in 1990; a loss which was greater than that which Russia had suffered in World War II (Stiglitz, 2002) (Figures2,3). In the words of Joseph-Stiglitz (2002):

The stabilization/liberalization/privatization program was, of course, not a growth program...-Instead, it set the preconditions for decline. Not only was investment halted, but capital was used up--savings vaporized by inflation, the proceeds of privatization or foreign loans largely misappropriated. Privatization, accompanied by the opening of the capital markets, led not to wealth creation but to asset stripping.-It was perfectly logical. An oligarch who has just been able to use political influence to garner assets worth billions, after paying only a pittance, would naturally want to get his money out of the country (p. 145).

Despite these signs, the IMF and WB continued the same policy. They were also very optimistic about the future because of the major decrease in inflation rates during 1995-1997. But in 1998, Russia was hit by a severe financial crisis. The IMF insisted on maintaining an overvalued fixed 
exchange rate, which required raising interest rates as high as $150 \%$ (Gilman, 2010). These policies not only led to excessive foreign debt burdens, but maintained a speculative bubble in the financial sphere and drained the real economy of investment capital. The overvalued ruble kept imports artificially cheap, damaged domestic production and resulted in exports being overly expensive (Peet, 2009). Eventually, the currency collapsed and on 17 August 1998, the Russian government devalued the ruble. Although the IMF responded with a loan of $\$ 22.6$ billion, with funds mainly from the WB and Japan, Russia's economy received a devastating impact.

These policies increased overall poverty and inequality. In 1989, only $2 \%$ of those living in Russia were in poverty. By late 1998, that number reached 23.8\% (\$2/day standard). Official unemployment rates rose steadily from $5.3 \%$ in 1992 to $13.5 \%$ in 1999 (Figure 2) and researchers reported that there was even higher disguised unemployment, since wages were frequently delayed in many sectors and when paid it was often in the form of goods (Stiglitz, 2002).
Hence, the IMF disturbed FS in Russia. The main reasons were:

(i) The IMF lost time when it was necessary to energetically support reforms and thus condemned Russia to prolonged crisis and stagnation (during-phase-one).

(ii) In the post socialist era, inflation had a nonmonetary character due to a special structure of the economy (highly-monopolistic,-lack-of-

bankruptcy-procedures,-etc.). Ordinary stabilization programs with excessive tightness condemned them to failure (Gaidar, 1997).

(iii) Fast-track capitalism tactics were ineffective in a society which previous regime was communism. The social and political factors underpinning the society were not taken seriously into consideration in the suggestions of the fiscal policy (World-Bank, 2000). The lack of knowledge of the Russian cultural, social and political circumstances (e.g. high corruption) led to multiple policy misjudgements (Garten, 1999; Anderson et al., 2000; Woods, 2006)

Inflation

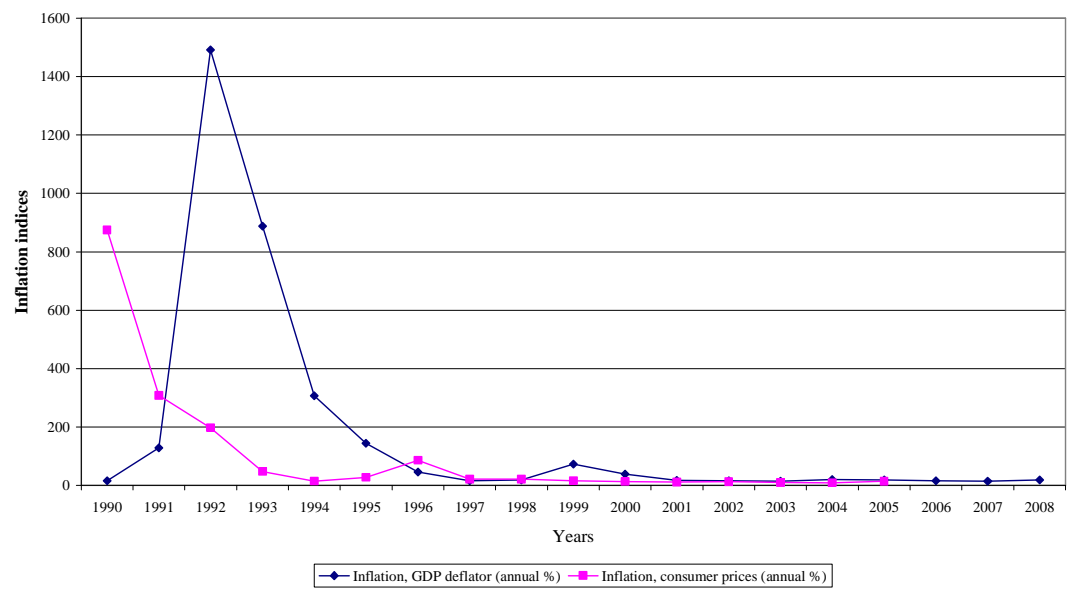

Fig. 1. Inflation-in-Russia-between-1990-and-2008 
Total Unemployment (\% of total labor force)

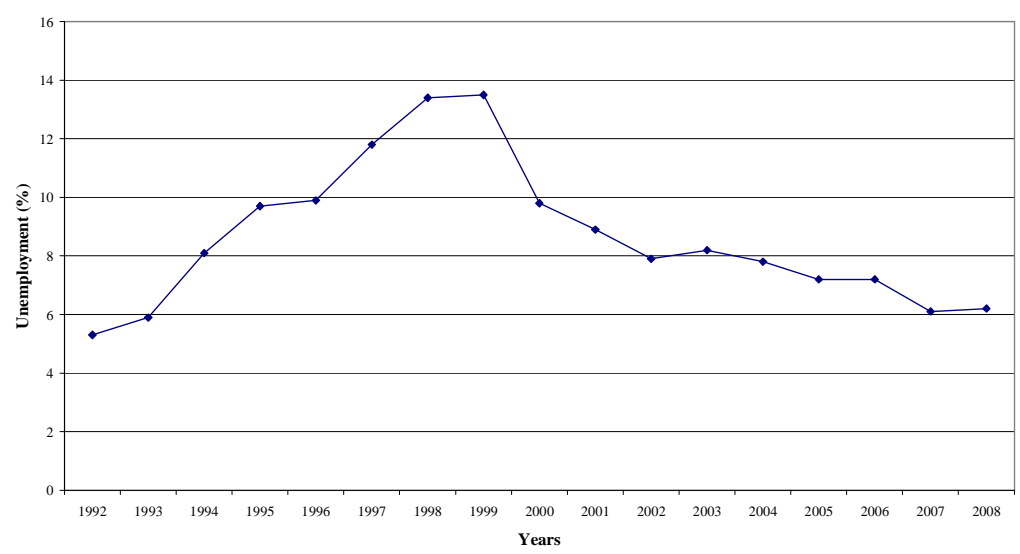

Fig. 2. Total-unemployment-in-Russia-between-1992-and-2008

GDP (current US\$)

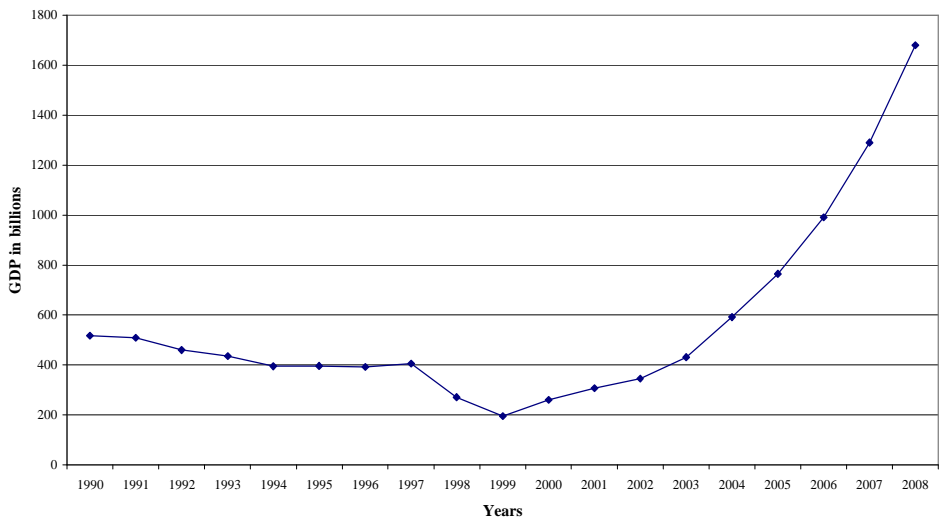

Fig. 3. GDP-(current-US\$)-in-Russia-between-1990-and-2008

\section{East Asian Financial Crisis}

The financial crisis on 2 July 1997 in East Asia (Malaysia, Korea, Philippines, Indonesia and Thailand) was the beginning of the greatest economic crisis resembling even that of the Great Depression (Stiglitz, 2002). The East Asian crisis came as a surprise because of the region's preceding long period of economic prosperity (YokoiArai, 2002) ( $^{\mathrm{ix}}$. Nevertheless, since 1996 and early 1997, the Thai baht was under speculative attack causing the Thai stock markets to fallx. At the same time, it became apparent that private enterprises in those nations would not be able to meet their payment obligations and international currency markets panicked ${ }^{\mathrm{xi}}$. Currency traders sought to convert their Asian money into dollars; and the Asian currencies collapsed. That made it harder for the Asian countries to pay their loans and it made imports suddenly very expensive (Haggard, 2003). In May 1997, Thailand was forced to impose certain exchange controls soon after the largest non-bank financial institution in Thailand became bankrupt, followed by the closure of multiple finance houses as well. Finally, the Thai government decided to float the baht, abandoning its peg to the dollar, thus leading to the advent of the financial crisis. As the crisis spread, most of Southeast Asia and Japan saw slumping currencies, devalued stock markets and other asset prices and a precipitous rise in private debt (Stiglitz, 2003). 
The IMF responded quickly and agreed to large support packages towards the countries which most needed: for Thailand $\$ 17.2$ billion, for Indonesia about $\$ 40$ billion and for South Korea $\$ 57$ billion (Fischer, 2003). Unfortunately, the IMF policies imposed during this critical time worsened the situation (Peet, 2009, p. 123). The IMF conditionality policies focused again on the Washington consensus: stabilization, privatization and liberalization of existing markets in order to restore confidence to international creditors. Their failure is shown in the sharp decrease of GDP (Figure 5) and rise of unemployment and inflation markers before and after the onset of the crisis (Figures 6,7).xii

\section{The Reason of the IMF's Failure}

The East Asian financial crisis has partially its roots in attempts for financial reform in the early 1990s--pressurized by the US Treasury and the IMF--that were aimed at upgrading financial institutions by relying on short-term foreign loans but in fact left individual economies exposed to the instabilities of international financial markets (Radelet et al., 1998; Dawson et al., 2003).xii

East Asian countries had no need for additional capital, given their high savings rate (Stiglitz, 2002). These liberalization policies were put forward even though there was little evidence that such policies promoted growth, and there was ample evidence that they imposed huge risks on developing countries. ${ }^{\text {xiv }}$

During the crisis, the IMF failed to restore market confidence and exchange rate stability by first declaring that the East Asian financial crisis was mainly the result of deep fundamental weaknesses, rather than a self-fulfilling panic among creditors (Barro, 2001). ${ }^{\mathrm{xv}}$ Announcing next large sums of money that were not readily available for short-term support didn't benefit the situation. Moreover, their approach to restoring market confidence was based on a very odd hypothesis: that tough action on restructuring financial markets--including closing financial institutions, tightening regulatory standards, etc.--would reassure creditors so much that they would roll over their short-term claims as they fell due. Creditors' confidence naturally collapsed after this by lowering vastly economic banking and letting failed institutions go bankrupt. International speculators went ballistic and continued the devaluation of the baht predominantly and the other currencies afterwards (Dawson, 2003).

The IMF's fiscal and monetary policy emphasised the need for strong fiscal contraction in order to ensure a fiscal surplus in 1998, even though the crisis countries were already hit hard by the contractionary force of the withdrawal of foreign credits. ${ }^{x v i}$ The IMF considered that such adjustments were the centrepiece of the confidence-building measures needed for currency stabilization. Yet, there is no evidence that the currency markets reacted at all favourably to the fiscal surplus targets. Even the IMF recognizes that their fiscal approach was faulty (Berg, 1999; ischer, 2003), and when they eased fiscal target in early 1998, the markets reacted positively. 
GDP per capita (1960-1996)

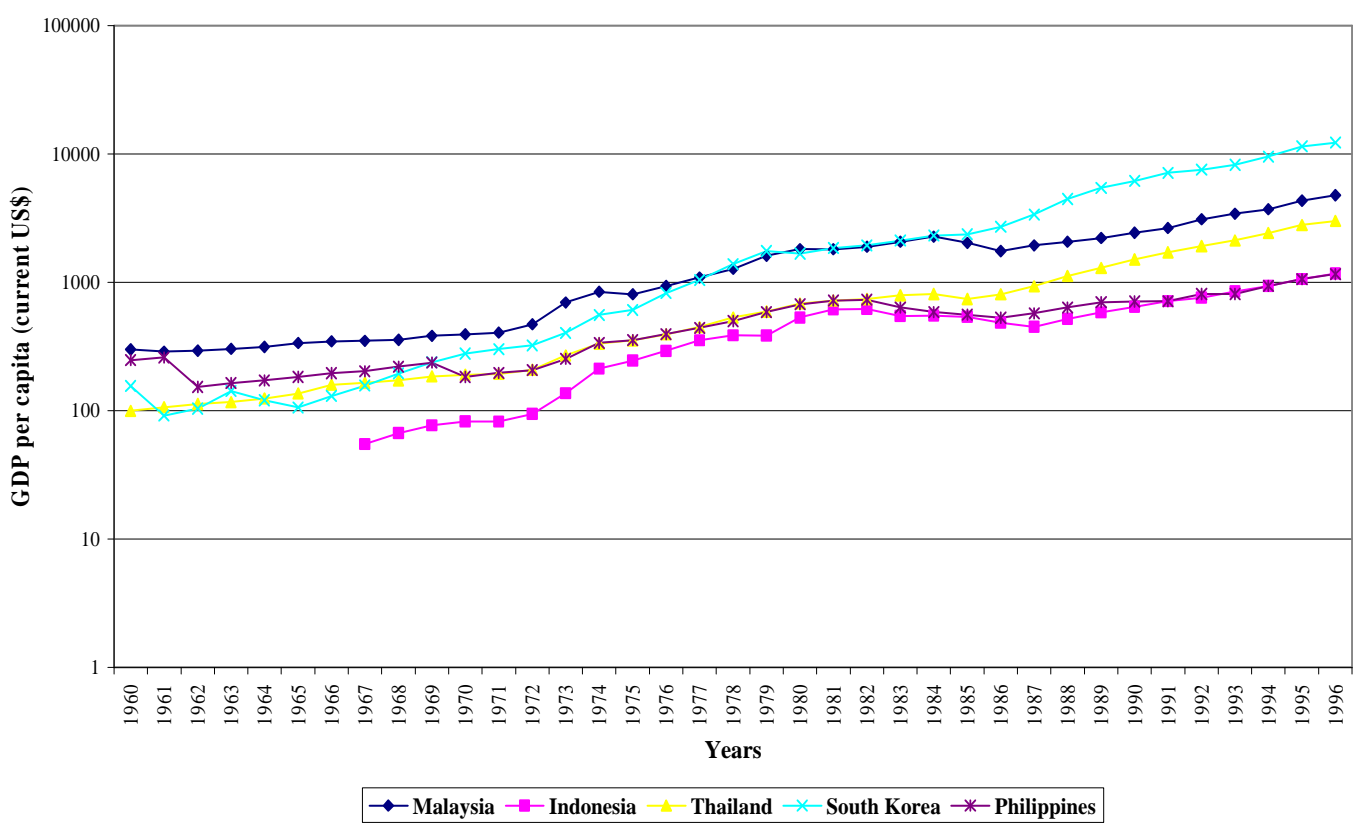

Fig. 4. GDP-per-capita-in-East-Asian-countries-between-1960-and-1996

GDP (current US\$)

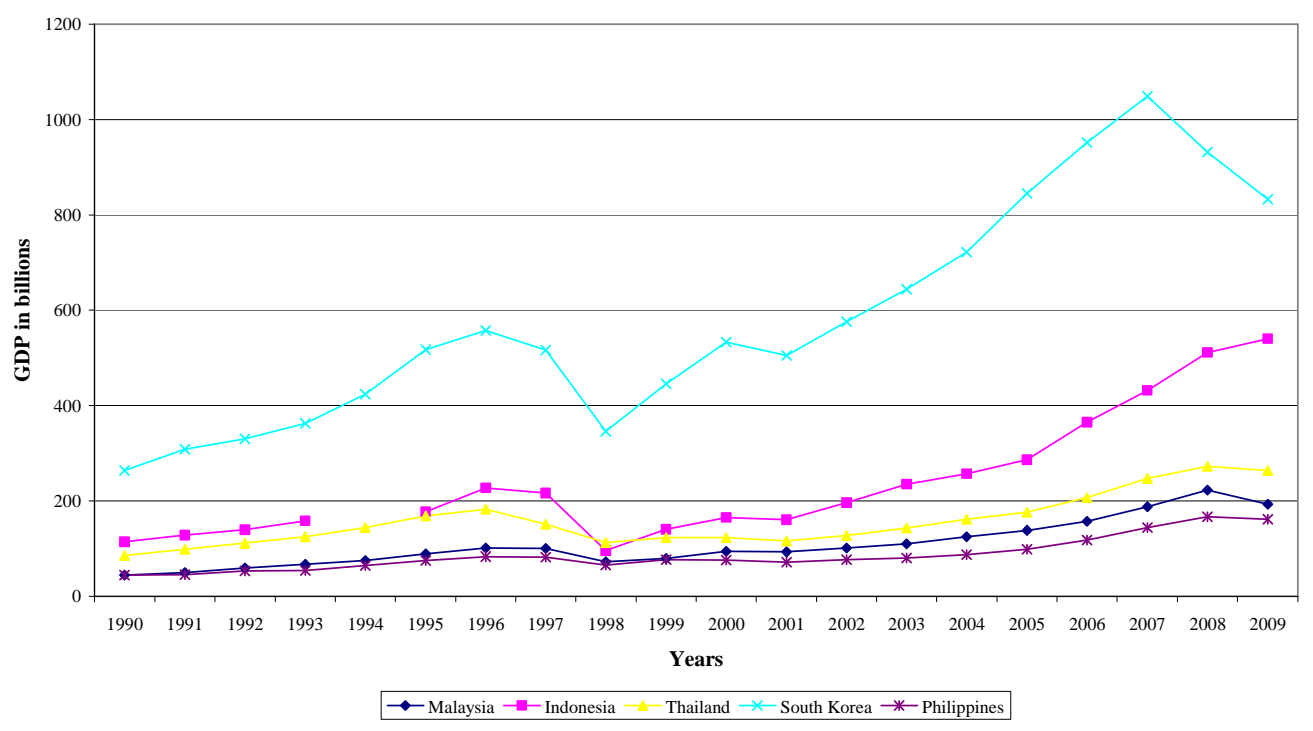

Fig. 5. GDP-(current-US\$)-in-East-Asian-countries-between-1990-and-2009 
Total Unemployment (\% of total labour force)

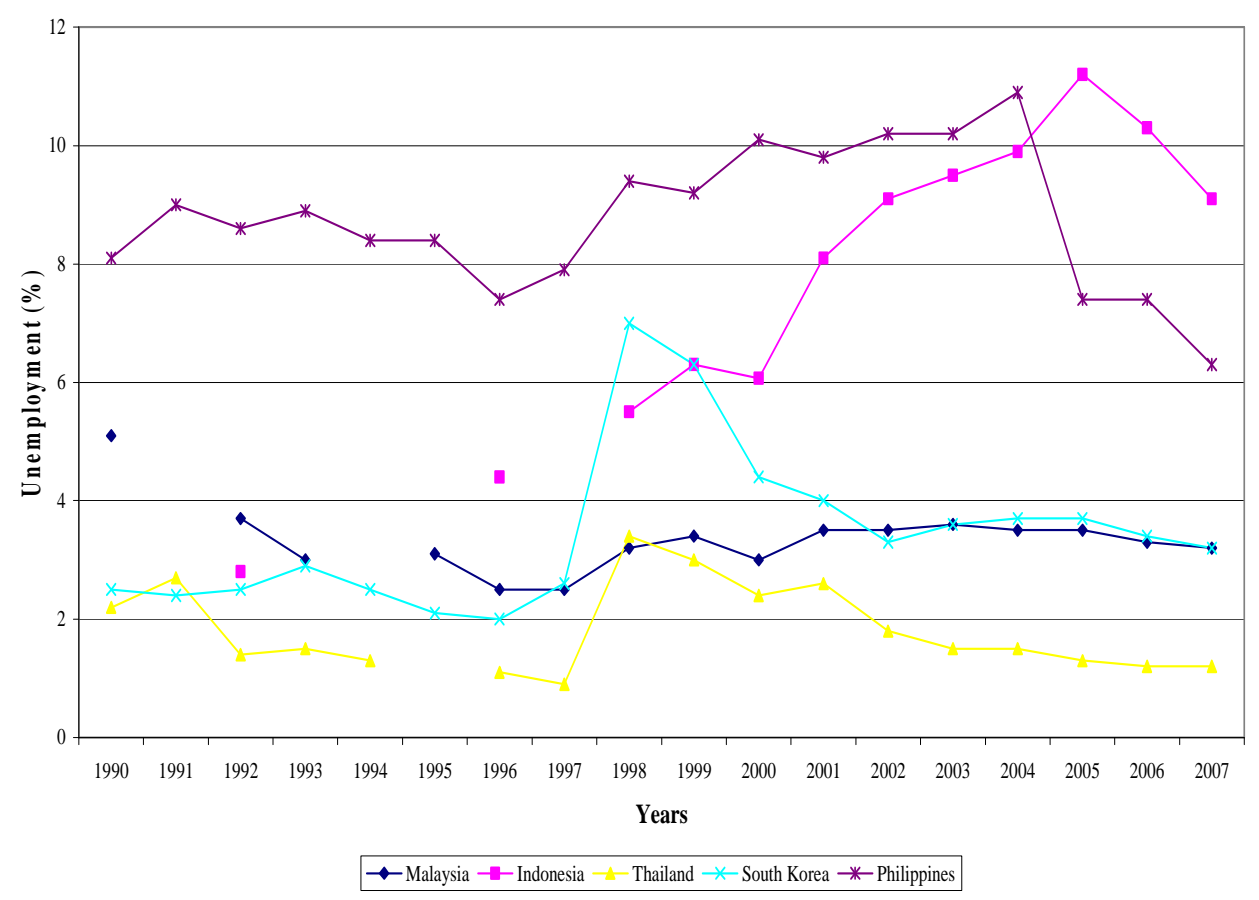

Fig. 6. Total-unemployment-in-East-Asian-countries-between-1990-and-2007

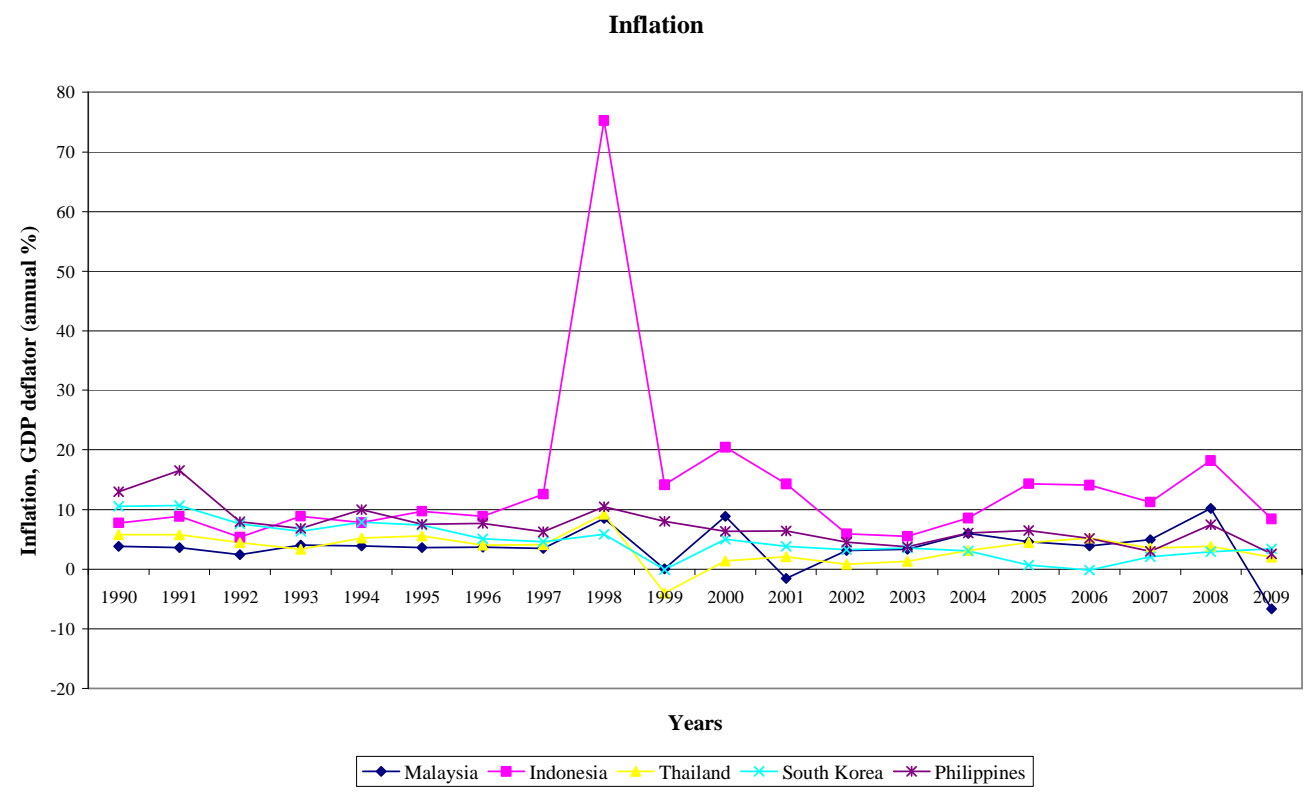

Fig. 7. Inflation-in-East-Asian-countries-between-1990-and-2009

Hence, in the Asian financial crisis, the IMF's policies deepened the recession. Only, Malaysia stood out as a country that refused IMF assistance and advice, suffering less severe economic problems. Instead of further opening its economy, Malaysia imposed capital controls, in an effort to eliminate speculative trading in its 
currency (Weisbrot et al., 2001). Despite the IMF's initial criticism, such a policy was later recognized as successful. Although the regional economy has now recovered, the lost growth and increased poverty is still significant.

\section{Quantitative Calculations Supporting Financial Instability}

In the previous section, there was a focus on describing financial instability in terms of unemployment, inflation and changes in GDP and GDP per capita. In the present section, an attempt to model certain indicators obtained form the World Bank will be made, depicting the changes of financial stability in a country and its dependence on IMF and World Bank loans. Thus, a country's financial instability is expressed by the following indicators (World-Bank, 2011):

1. GDP Annual Growth Rate (AGR): Annual percentage growth rate of GDP at market prices based on constant local currency. Aggregates are based on constant 2000 U.S. dollars. GDP is the sum of gross value added by all resident producers in the economy plus any product taxes and minus any subsidies not included in the value of the products. It is calculated without making deductions for depreciation of fabricated assets or for depletion and degradation of natural resources.

2. Interest Rate Spread (Lending Rate Minus Deposit Rate, \%) (IRS): Interest rate spread is the interest rate charged by banks on loans to prime customers minus the interest rate paid by commercial or similar banks for demand, time or savings deposits.

\section{Inflation, GDP Deflator (annual \%)} (INF): Inflation as measured by the annual growth rate of the GDP implicit deflator, which shows the rate of price change in the economy as a whole. The GDP implicit deflator is the ratio of GDP in current local currency to GDP in constant local currency. Another measure used is the Inflation as measured by the consumer price index, which reflects the annual percentage change in the cost to the average consumer of acquiring a basket of goods and services that may be fixed or changed at specified intervals, such as yearly. The Laspeyres formula is generally used.

4. Annual Industrial Value (AIV): Industry, value added (annual \% growth). Annual growth rate for industrial value added based on constant local currency. Aggregates are based on constant 2000 U.S. dollars. Industry corresponds to ISIC divisions 10-45 and includes manufacturing (ISIC divisions 15-37). It comprises value added in mining, manufacturing (also reported as a separate subgroup), construction, electricity, water and gas. Value added is the net output of a sector after adding up all outputs and subtracting intermediate inputs. It is calculated without making deductions for depreciation of fabricated assets or depletion and degradation of natural resources. The origin of value added is determined by the International Standard Industrial Classification (ISIC), revision 3.

5. GINI Index (GINI): Gini index measures the extent to which the distribution of income (or, in some cases, consumption expenditure) among individuals or households within an economy deviates from a perfectly equal distribution. A Lorenz curve plots the cumulative percentages of total income received against the cumulative number of recipients, starting with the poorest individual or household. The Gini index measures the area between the Lorenz curve and a hypothetical line of absolute equality, expressed as a percentage of the maximum area under the line. Thus a Gini index of 0 represents perfect equality, while an index of 100 implies perfect inequality.

The researchers performed multiple linear regressions in PASW 18.0 using the previous variables as dependent variables. The independent variables are:

1. IMF Charges over Interest Payments (IMFc): IMF charges cover interest payments with respect to all uses of IMF resources, excluding those resulting from 
drawings in the reserve tranche. Data are in current U.S. dollars.

\section{IBRD Loans and IDA Credits (DOD,} Current US\$) (IBRDL): IBRD loans and IDA credits are public and publicly guaranteed debt extended by the World Bank Group. The International Bank for Reconstruction and Development (IBRD) lends at market rates. Credits from the International Development Association (IDA) are at concessional rates. Data are in current U.S. dollars.

3. Cross Currency Valuation (CCV): Cross-currency valuation shows the change in debt stock due to cross-currency valuation effects. Cross-currency valuation effects arise from movements in the value of the U.S. dollar against other world currencies as well as debt forgiveness or reduction, and affect the value of developing country debt. Countries contract debt in various currencies. The debt data that countries report to the DRS is expressed in the currencies in which the original debt was contracted or in currencies in which it is repayable. For purposes of standardization and aggregation, the DRS converts these amounts into dollar values. The exchange rates used are generally the par values or central rates specified by the IMF or market rates when necessary. Exchange rates in effect at the end of any given year are used to convert the stock of debt outstanding for that year in various currencies into the nominal dollar value. Data are in current U.S. dollars.

The models are: 1st Linear Regression Model:

$$
A G R=C_{0}+C_{1}\left(I M F d+C_{2}\left(I B R D \not+C_{3}(C C V)+\varepsilon\right.\right.
$$

2nd Linear Regression Model:

$$
I R S=A_{0}+A_{1}(I M F C)+A_{2}(I B R D L)+\varepsilon
$$

3rd Linear Regression Model:

$$
I R S=F_{0}+F_{1}\left(I M F d+F_{2}\left(I B R D L+F_{3}(C C V)+\mathcal{E}\right.\right.
$$

4th Linear Regression Model:

$$
I N F=B_{0}+B_{1}(I M F C)+B_{2}(I B R D L)+\varepsilon
$$

5th Linear Regression Model:

$$
A I V=D_{0}+D_{1}(I M F c)+D_{2}(I B R D L)+\varepsilon
$$

6th Linear Regression Model:

$G I N I=E_{0}+E_{1}(I M F c)+E_{2}(I B R D L)+\varepsilon$ , where $\varepsilon$ is the error term in each regression

The results for Russia are shown in Table 1 and for East Asia countries in Table 2. 
Table 1. Linear Regression Models for Russia

\begin{tabular}{|c|c|c|c|c|}
\hline & \multicolumn{4}{|c|}{ Russia } \\
\hline \multirow[t]{3}{*}{ Variables } & \multicolumn{2}{|c|}{$\begin{array}{l}\text { Unstandardised } \\
\text { Coefficients }\end{array}$} & \multirow{2}{*}{$\begin{array}{c}\begin{array}{c}\text { Standardised } \\
\text { Coefficients }\end{array} \\
\text { Beta }\end{array}$} & \multirow[t]{2}{*}{ p-value } \\
\hline & B & SE & & \\
\hline & \multicolumn{4}{|c|}{$\begin{array}{l}\text { Model 1: Dependent Variable AGR } \\
\text { R-squared:0.822; Adjusted R-squared: } 0.781 \\
\text { ANOVA: F=20.002; } \mathbf{p}<0.0001\end{array}$} \\
\hline (Constant) & -9.520 & 1.864 & & $<0.0001$ \\
\hline IMFc & $-1.356 \times 10^{-8}$ & 0.000 & -0.482 & 0.005 \\
\hline IBRDL & $3.325 \times 10^{-9}$ & 0.000 & 1.031 & $<0.0001$ \\
\hline \multirow[t]{2}{*}{$\mathrm{CCV}$} & $-4.590 \times 10^{-10}$ & 0.000 & -0.226 & 0.100 \\
\hline & \multicolumn{4}{|c|}{$\begin{array}{l}\text { Model 2: Dependent Variable IRS } \\
\text { R-squared:0.690; Adjusted R-squared: } 0.634 \\
\text { ANOVA: F=12.257; } \mathrm{p}=0.002\end{array}$} \\
\hline (Constant) & 161.925 & 31.691 & & $<0.0001$ \\
\hline IMFc & $8.483 \times 10^{-8}$ & 0.000 & 0.422 & 0.037 \\
\hline \multirow[t]{2}{*}{ IBRDL } & $-3.021 \times 10^{-8}$ & 0.000 & -0.866 & $<0.0001$ \\
\hline & \multicolumn{4}{|c|}{$\begin{array}{l}\text { Model 3: Dependent Variable IRS } \\
\text { R-squared:0.814; Adjusted R-squared: } 0.758 \\
\text { ANOVA: } F=14.546 ; p=0.001\end{array}$} \\
\hline (Constant) & 162.917 & 25.79 & & $<0.0001$ \\
\hline IMFc & $1.241 \times 10^{-7}$ & 0.000 & 0.617 & 0.004 \\
\hline IBRDL & $-3.239 \times 10^{-8}$ & 0.000 & -0.928 & $p<0.0001$ \\
\hline \multirow[t]{2}{*}{ CCV } & $5.776 \times 10^{-9}$ & 0.000 & 0.397 & 0.028 \\
\hline & \multicolumn{4}{|c|}{$\begin{array}{l}\text { Model 4: Dependent Variable INF } \\
\text { R-squared:0.516; Adjusted R-squared: } 0.447 \\
\text { ANOVA: F=7.467; } p=0.006\end{array}$} \\
\hline (Constant) & 698.069 & 151.851 & & $<0.0001$ \\
\hline IMFc & $7.963 \times 10^{-9}$ & 0.000 & 0.006 & 0.979 \\
\hline \multirow[t]{2}{*}{ IBRDL } & $-1.192 \times 10^{-7}$ & 0.000 & -0.721 & 0.004 \\
\hline & \multicolumn{4}{|c|}{$\begin{array}{l}\text { Model 5: Dependent Variable AIV } \\
\text { R-squared:0.795; Adjusted R-squared: } 0.766 \\
\text { ANOVA: F=27.227; p }<0.0001\end{array}$} \\
\hline (Constant) & -15.518 & 2.475 & & $<0.0001$ \\
\hline IMFc & $-7.292 \times 10^{-9}$ & 0.000 & -0.202 & 0.159 \\
\hline \multirow[t]{2}{*}{ IBRDL } & $4.001 \times 10^{-9}$ & 0.000 & 0.965 & $\mathrm{p}<0.0001$ \\
\hline & \multicolumn{4}{|c|}{$\begin{array}{l}\text { Model 6: Dependent Variable GINI } \\
\text { R-squared:0.873; Adjusted R-squared: } 0.810 \\
\text { ANOVA: F=13.756; p<0.016 }\end{array}$} \\
\hline (Constant) & 49.459 & 1.840 & & $<0.0001$ \\
\hline IMFc & $3.151 \times 10^{-9}$ & 0.000 & 0.182 & 0.406 \\
\hline IBRDL & $-1.984 \times 10^{-9}$ & 0.000 & -0.995 & 0.007 \\
\hline
\end{tabular}


The interesting points from these models are:

- The models are very good for Russia and relatively satisfactory for Thailand and the Philippines; they don't perform so well in the case of Malaysia, Indonesia and South Korea. This can be seen by assessing the R-square, the adjusted Rsquare and the significance of the models (ANOVA) shown in Tables 1 and 2.

- IMF charges are negatively and significantly associated with annual GDP growth for all East Asian countries and Russia. This indicates that the higher IMF charges are the lower the annual GDP growth.

- The increase in IMF charges is positively associated with increase in interest rates, which causes financial problems in borrowing for each country.
- IMF charges didn't have any significant effect on inflation, but IBRD loans (World Bank credit) seem to decrease inflation. This could be beneficial for a country's economy. GINI coefficient also had no significant relationship with IMF charges or IBRD loans.

- Annual industrial value negatively and significantly associated with IMF charges only in the case of Thailand and Philippines, signifying that the presence of the IMF decreases the country's industrial value.

- Annual GDP growth is negatively associated with Cross-Currency Swaps in the case of Russia, something that was promoted in Russia according to IMF guidelines. 
Table 2. Linear Regression Results for East Asian Countries

\begin{tabular}{|c|c|c|c|c|c|c|c|c|c|c|c|c|c|c|c|c|c|c|c|}
\hline \multirow{3}{*}{$\begin{array}{l}\text { coun } \\
\text { tries } \\
\text { Varia } \\
\text { bles }\end{array}$} & \multicolumn{4}{|c|}{ Thailand } & \multicolumn{4}{|c|}{ Malaysia } & \multicolumn{3}{|c|}{ South Korea } & \multicolumn{4}{|c|}{ Indonesia } & \multicolumn{4}{|c|}{ Philippines } \\
\hline & \multicolumn{2}{|c|}{$\begin{array}{c}\text { Unstanda } \\
\text { rdised } \\
\text { Coefficie } \\
\text { nts }\end{array}$} & \multirow{2}{*}{$\begin{array}{c}\text { Standa } \\
\text { rdised } \\
\text { Coeffic } \\
\text { ients } \\
\text { Beta } \\
\end{array}$} & \multirow[t]{2}{*}{$\begin{array}{c}\text { p- } \\
\text { valu } \\
\text { e }\end{array}$} & \multicolumn{2}{|c|}{$\begin{array}{l}\text { Unstanda } \\
\text { rdised } \\
\text { Coefficie } \\
\text { nts }\end{array}$} & \multirow{2}{*}{\begin{tabular}{|c|}
$\begin{array}{c}\text { Standa } \\
\text { rdised } \\
\text { Coeffic } \\
\text { ients }\end{array}$ \\
Beta \\
\end{tabular}} & \multirow[t]{2}{*}{$\begin{array}{c}\text { p- } \\
\text { val } \\
\text { ue }\end{array}$} & $\begin{array}{l}\text { Unstanda } \\
\text { rdised } \\
\text { Coefficie } \\
\text { nts }\end{array}$ & \multirow{2}{*}{$\begin{array}{c}\text { Standa } \\
\text { rdised } \\
\text { Coeffic } \\
\text { ients } \\
\text { Beta } \\
\end{array}$} & \multirow[t]{2}{*}{$\begin{array}{c}\text { p- } \\
\text { va } \\
\text { lu } \\
\text { e }\end{array}$} & \multicolumn{2}{|c|}{$\begin{array}{l}\text { Unstanda } \\
\text { rdised } \\
\text { Coefficien } \\
\text { ts }\end{array}$} & \multirow[t]{2}{*}{$\begin{array}{c}\text { Standa } \\
\text { rdised } \\
\text { Coeffic } \\
\text { ients } \\
\text { Beta } \\
\end{array}$} & \multirow[t]{2}{*}{$\begin{array}{c}\text { p- } \\
\text { val } \\
\text { ue }\end{array}$} & \multicolumn{2}{|c|}{$\begin{array}{l}\text { Unstanda } \\
\text { rdised } \\
\text { Coefficie } \\
\text { nts }\end{array}$} & \multirow{2}{*}{$\begin{array}{c}\text { Standa } \\
\text { rdised } \\
\text { Coeffic } \\
\text { ients } \\
\text { Beta } \\
\end{array}$} & \multirow[t]{2}{*}{$\begin{array}{l}\text { p- } \\
\text { val } \\
\text { ue }\end{array}$} \\
\hline & B & SE & & & B & SE & & & \begin{tabular}{l|l} 
B & SE \\
\end{tabular} & & & B & SE & & & B & SE & & \\
\hline & \multicolumn{4}{|c|}{$\begin{array}{l}\text { Model 1: Dependent } \\
\text { Variable AGR } \\
\text { R-squared:0.222; Adjusted } \\
\text { R-squared: } 0.180 \\
\text { ANOVA: F=5.289; } p=0.010\end{array}$} & \multicolumn{4}{|c|}{$\begin{array}{l}\text { Model 1: Dependent } \\
\text { Variable AGR } \\
\text { R-squared:0.030 } \\
\text { ANOVA: } F=0.568 ; p=0.572\end{array}$} & \multicolumn{3}{|c|}{$\begin{array}{l}\text { Model 1: Dependent } \\
\text { Variable AGR } \\
\text { Not applicable (no IMFc } \\
\text { data for South Korea) }\end{array}$} & \multicolumn{4}{|c|}{$\begin{array}{l}\text { Model 1: Dependent } \\
\text { Variable AGR } \\
\text { R-squared:0.161; Adjusted } \\
\text { R-squared: } 0.115 \\
\text { ANOVA: F=3.543; } p=0.039\end{array}$} & \multicolumn{4}{|c|}{$\begin{array}{l}\text { Model 1: Dependent } \\
\text { Variable AGR } \\
\text { R-squared:0.183; Adjusted } \\
\text { R-squared: } 0.139 \\
\text { ANOVA: } F=4.152 ; p=0.024 \\
\end{array}$} \\
\hline $\begin{array}{l}\text { (Con } \\
\text { stant } \\
\text { ) }\end{array}$ & $\begin{array}{l}5.4 \\
48\end{array}$ & $\begin{array}{l}0 . \\
96 \\
0 \\
\end{array}$ & & $\begin{array}{l}<0.0 \\
001\end{array}$ & $\begin{array}{l}6.0 \\
36\end{array}$ & $\begin{array}{l}1 . \\
19 \\
9 \\
\end{array}$ & & $\begin{array}{l}<0 \\
000 \\
1\end{array}$ & & & & $\begin{array}{l}7.0 \\
97\end{array}$ & $\begin{array}{l}1.0 \\
06\end{array}$ & & $\begin{array}{l}<0 \\
000 \\
1 \\
\end{array}$ & $\begin{array}{l}5.7 \\
06\end{array}$ & $\begin{array}{l}0 . \\
88 \\
9 \\
\end{array}$ & & $\begin{array}{l}<0 \\
000 \\
1 \\
\end{array}$ \\
\hline IMFc & $\begin{array}{l}- \\
5.6 \\
71 \mathrm{x} \\
10^{-8}\end{array}$ & $\begin{array}{l}0 . \\
00 \\
0\end{array}$ & -0.640 & $\begin{array}{l}0.00 \\
3\end{array}$ & $\begin{array}{l} \\
9.6 \\
15 \mathrm{x} \\
10^{-8}\end{array}$ & $\begin{array}{l}0 . \\
00 \\
0\end{array}$ & -0.151 & $\begin{array}{l}0.3 \\
58\end{array}$ & & & & $\begin{array}{l}- \\
8.3 \\
57 \\
x \\
10 \\
9\end{array}$ & $\begin{array}{l}0.0 \\
00\end{array}$ & -0.306 & $\begin{array}{l}0.0 \\
81\end{array}$ & $\begin{array}{l}- \\
4.0 \\
77 \mathrm{x} \\
10^{-8}\end{array}$ & $\begin{array}{l}0 . \\
00 \\
0\end{array}$ & -0.449 & $\begin{array}{l}0.0 \\
15\end{array}$ \\
\hline $\begin{array}{l}\text { IBRD } \\
\text { L }\end{array}$ & $\begin{array}{l}1.8 \\
16 \mathrm{x} \\
10^{-9}\end{array}$ & $\begin{array}{l}0 . \\
00 \\
0\end{array}$ & 0.498 & $\begin{array}{l}0.01 \\
7\end{array}$ & $\begin{array}{l}9.4 \\
95 \mathrm{x} \\
10^{-} \\
10\end{array}$ & $\begin{array}{l}0 . \\
00 \\
0\end{array}$ & 0.093 & $\begin{array}{l}0.5 \\
68\end{array}$ & & & & $\begin{array}{l} \\
1.2 \\
13 \\
x \\
10 \\
10\end{array}$ & $\begin{array}{l}0.0 \\
00\end{array}$ & -0.152 & $\begin{array}{l}0.3 \\
81\end{array}$ & $\begin{array}{l}7.4 \\
33 \mathrm{x} \\
10^{-} \\
11\end{array}$ & $\begin{array}{l}0 . \\
00 \\
0\end{array}$ & 0.040 & $\begin{array}{l}0.8 \\
21\end{array}$ \\
\hline & \multicolumn{4}{|c|}{$\begin{array}{l}\text { Model 2: Dependent } \\
\text { Variable IRS } \\
\text { R-squared:0.388; Adjusted } \\
\text { R-squared: } 0.347 \\
\text { ANOVA: F=9.508; } p=0.001\end{array}$} & \multicolumn{4}{|c|}{$\begin{array}{l}\text { Model 2: Dependent } \\
\text { Variable IRS } \\
\text { ANOVA: F=1.303; } p=0.267 \\
\text { Model not significant }\end{array}$} & \multicolumn{3}{|c|}{$\begin{array}{l}\text { Model 2: Dependent } \\
\text { Variable IRS } \\
\text { Not applicable (no IMFc } \\
\text { data for South Korea) }\end{array}$} & \multicolumn{4}{|c|}{$\begin{array}{l}\text { Model 2: Dependent } \\
\text { Variable IRS } \\
\text { R-squared:0.136; Adjusted } \\
\text { R-squared: } 0.054 \\
\text { ANOVA: } F=1.650 ; p=0.216\end{array}$} & \multicolumn{4}{|c|}{$\begin{array}{l}\text { Model 2: Dependent } \\
\text { Variable IRS } \\
\text { R-squared:0.113; Adjusted } \\
\text { R-squared: } 0.056 \\
\text { ANOVA: F=1.976; } \mathrm{p}=\mathbf{0 . 1 5 6}\end{array}$} \\
\hline $\begin{array}{l}\text { (Con } \\
\text { stant } \\
\text { ) }\end{array}$ & $\begin{array}{l}4.0 \\
89\end{array}$ & $\begin{array}{l}0 . \\
24 \\
5\end{array}$ & & $\begin{array}{l}<0.0 \\
001\end{array}$ & & & & & & & & $\begin{array}{l}5.2 \\
85\end{array}$ & $\begin{array}{l}.99 \\
6\end{array}$ & & $\begin{array}{l}<0 \\
000 \\
1\end{array}$ & $\begin{array}{l}6.2 \\
99\end{array}$ & $\begin{array}{l}0 . \\
87 \\
8 \\
\end{array}$ & & $\begin{array}{l}<0 \\
000 \\
1\end{array}$ \\
\hline IMFc & $\begin{array}{l}1.6 \\
94 \mathrm{x} \\
10^{-8}\end{array}$ & $\begin{array}{l}0 . \\
00 \\
0\end{array}$ & 0.736 & $\begin{array}{l}0.00 \\
1\end{array}$ & & & & & & & & $\begin{array}{l}3.9 \\
57 \\
x \\
10 \\
9\end{array}$ & $\begin{array}{l}0.0 \\
00\end{array}$ & 0.197 & $\begin{array}{l}0.4 \\
03\end{array}$ & $\begin{array}{l}1.8 \\
73 \mathrm{x} \\
10^{-8}\end{array}$ & $\begin{array}{l}0 . \\
00 \\
0\end{array}$ & 0.237 & $\begin{array}{l}0.2 \\
46\end{array}$ \\
\hline $\begin{array}{l}\text { IBRD } \\
\text { L }\end{array}$ & $\begin{array}{l} \\
7.7 \\
31 x \\
10^{-} \\
10\end{array}$ & $\begin{array}{l}0 . \\
00 \\
0\end{array}$ & -0.817 & $\begin{array}{l}\mathrm{p}<0 \\
000 \\
1\end{array}$ & & & & & & & & $\begin{array}{l} \\
2.4 \\
66 \\
x \\
10 \\
10\end{array}$ & $\begin{array}{l}0.0 \\
00\end{array}$ & -0.418 & $\begin{array}{l}0.0 \\
84\end{array}$ & $\begin{array}{l}- \\
6.3 \\
77 \mathrm{x} \\
10^{-} \\
10\end{array}$ & $\begin{array}{l}0 . \\
00 \\
0\end{array}$ & -0.398 & $\begin{array}{l}0.0 \\
56\end{array}$ \\
\hline & $\begin{array}{l}\text { Mod } \\
\text { Vari: } \\
\text { R-sq } \\
\text { R-sq } \\
\text { ANO } \\
\end{array}$ & $\begin{array}{l}\text { 14: D } \\
\text { ole II } \\
\text { ared } \\
\text { ared } \\
\mathrm{A}: \mathrm{F}=\end{array}$ & $\begin{array}{l}\text { pendent } \\
.086 ; \mathrm{Ad} \\
.037 \\
.744 ; \mathrm{p}=\end{array}$ & Isted & $\begin{array}{l}\text { Mode } \\
\text { Varia } \\
\text { R-sq } \\
\text { ANOI }\end{array}$ & $\begin{array}{l}\text { 4: D } \\
\text { ple II } \\
\text { ared } \\
A: F=\end{array}$ & $\begin{array}{l}\text { pendent } \\
.025 \\
.474 ; p=\end{array}$ & & $\begin{array}{l}\text { Model 4: D } \\
\text { Variable IN } \\
\text { Not applica } \\
\text { data for So }\end{array}$ & $\begin{array}{l}\text { pendent } \\
\text { F } \\
\text { ble (no IMF } \\
\text { th Korea) }\end{array}$ & & $\begin{array}{l}\text { Moc } \\
\text { Var } \\
\text { R-s } \\
\text { ANC }\end{array}$ & $\begin{array}{l}\text { 1 4: D } \\
\text { ble IN } \\
\text { ared } \\
\mathrm{A}: \mathrm{F}=\end{array}$ & $\begin{array}{l}\text { pendent } \\
.047 \\
.920 ; p=\end{array}$ & & $\begin{array}{l}\text { Mod } \\
\text { Vari: } \\
\text { R-sq } \\
\text { R-sq } \\
\text { ANO } \\
\end{array}$ & $\begin{array}{l}\text { F: } \\
\text { le II } \\
\text { ared } \\
\text { ared } \\
\text { A: } F=\end{array}$ & $\begin{array}{l}\text { pendent } \\
.151 ; \mathrm{Ad} \\
0.105 \\
.278 ; \mathrm{p}=\end{array}$ & $\begin{array}{l}\text { Isted } \\
049 \\
\end{array}$ \\
\hline $\begin{array}{l}\text { (Con } \\
\text { stant } \\
\text { ) }\end{array}$ & $\begin{array}{l}5.8 \\
67\end{array}$ & $\begin{array}{l}1 . \\
20 \\
7 \\
\end{array}$ & & $\begin{array}{l}<0.0 \\
001\end{array}$ & $\begin{array}{l}4.5 \\
63\end{array}$ & $\begin{array}{l}1 . \\
73 \\
4 \\
\end{array}$ & & $\begin{array}{l}0.0 \\
12\end{array}$ & & & & $\begin{array}{l}92 . \\
04 \\
3 \\
\end{array}$ & $\begin{array}{l}47 . \\
81 \\
8 \\
\end{array}$ & & $\begin{array}{l}0.0 \\
62\end{array}$ & $\begin{array}{l}12 . \\
163\end{array}$ & $\begin{array}{l}2 . \\
50 \\
2 \\
\end{array}$ & & $\begin{array}{l}<0 . \\
000 \\
1\end{array}$ \\
\hline IMFc & $\begin{array}{l}- \\
1.4 \\
36 \mathrm{x} \\
10^{-8}\end{array}$ & $\begin{array}{l}0 . \\
00 \\
0\end{array}$ & -0.140 & $\begin{array}{l}0.52 \\
0\end{array}$ & $\begin{array}{l}- \\
8.1 \\
78 \mathrm{x} \\
10^{-8}\end{array}$ & $\begin{array}{l}0 . \\
00 \\
0\end{array}$ & -0.089 & $\begin{array}{l}0.5 \\
87\end{array}$ & & & & $\begin{array}{l}2.3 \\
82 \\
x \\
10 \\
7\end{array}$ & $\begin{array}{l}0.0 \\
00\end{array}$ & 0.196 & $\begin{array}{l}0.2 \\
90\end{array}$ & $\begin{array}{l}8.0 \\
98 \mathrm{x} \\
10^{-8}\end{array}$ & $\begin{array}{l}0 . \\
00 \\
0\end{array}$ & 0.323 & $\begin{array}{l}0.0 \\
81\end{array}$ \\
\hline $\begin{array}{l}\text { IBRD } \\
\text { L }\end{array}$ & $\begin{array}{l}- \\
7.5 \\
98 \mathrm{x} \\
10^{-} \\
10\end{array}$ & $\begin{array}{l}0 . \\
00 \\
0\end{array}$ & -0.180 & $\begin{array}{l}0.40 \\
9\end{array}$ & $\begin{array}{l}- \\
1.8 \\
33 \mathrm{x} \\
10^{-9}\end{array}$ & $\begin{array}{l}0 . \\
00 \\
0\end{array}$ & -0.125 & $\begin{array}{l}0.4 \\
47\end{array}$ & & & & $\begin{array}{l}- \\
8.0 \\
46 \\
x \\
10^{-} \\
9\end{array}$ & $\begin{array}{l}0.0 \\
00\end{array}$ & -0.225 & $\begin{array}{l}0.2 \\
24\end{array}$ & $\begin{array}{l}- \\
2.2 \\
93 \mathrm{x} \\
10^{-9}\end{array}$ & $\begin{array}{l}0 . \\
00 \\
0\end{array}$ & -0.451 & $\begin{array}{l}0.0 \\
17\end{array}$ \\
\hline & $\begin{array}{l}\text { Mod } \\
\text { Vari } \\
\text { R-sq } \\
\text { R-sq } \\
\text { ANO } \\
\end{array}$ & $\begin{array}{l}\text { 5: D } \\
\text { le A } \\
\text { ared } \\
\text { ared } \\
\text { A: } F=\end{array}$ & $\begin{array}{l}\text { pendent } \\
.208 \text {; Ad } \\
.165 \\
.8481 \mathrm{p}=\end{array}$ & $\begin{array}{l}\text { Isted } \\
013\end{array}$ & $\begin{array}{l}\text { Mode } \\
\text { Varia } \\
\text { R-sq } \\
\text { R-sq } \\
\text { ANOI }\end{array}$ & $\begin{array}{l}5: D \\
\text { le A } \\
\text { ared } \\
\text { ared } \\
\text { A: } F=\end{array}$ & $\begin{array}{l}\text { pendent } \\
.058 ; \mathrm{Ad} \\
0.005 \\
.100 ; \mathrm{p}=\end{array}$ & $\begin{array}{l}\text { Isted } \\
344 \\
\end{array}$ & $\begin{array}{l}\text { Model 5: D } \\
\text { Variable A } \\
\text { Not applica } \\
\text { data for So }\end{array}$ & $\begin{array}{l}\text { pendent } \\
V \\
\text { ble (no IMF } \\
\text { th Korea) }\end{array}$ & & $\begin{array}{l}\text { Moc } \\
\text { Var } \\
\text { R-s } \\
\text { R-s } \\
\text { ANC }\end{array}$ & $\begin{array}{l}\text { 15: D } \\
\text { ble } A \\
\text { ared } \\
\text { ared } \\
\mathrm{A}: \mathrm{F}=\end{array}$ & $\begin{array}{l}\text { pendent } \\
.123 ; \mathrm{Ad} \\
0.076 \\
.606 ; \mathrm{p}=\end{array}$ & $\begin{array}{l}\text { Isted } \\
087 \\
\end{array}$ & $\begin{array}{l}\text { Mod } \\
\text { Vari } \\
\text { R-sq } \\
\text { R-sq } \\
\text { ANO } \\
\end{array}$ & $\begin{array}{l}\text { le } A \\
\text { ared } \\
\text { ared } \\
A: F=\end{array}$ & $\begin{array}{l}\text { pendent } \\
.190 ; \text { Ad } \\
0.146 \\
.328 ; p=\end{array}$ & $\begin{array}{l}\text { Isted } \\
020\end{array}$ \\
\hline $\begin{array}{l}\text { (Con } \\
\text { stant } \\
\text { ) }\end{array}$ & $\begin{array}{l}6.9 \\
77\end{array}$ & $\begin{array}{l}1 . \\
42 \\
0 \\
\end{array}$ & & $\begin{array}{l}<0.0 \\
001\end{array}$ & $\begin{array}{l}4.2 \\
81\end{array}$ & $\begin{array}{l}2 . \\
01 \\
2 \\
\end{array}$ & & $\begin{array}{l}0.0 \\
40\end{array}$ & & & & $\begin{array}{l}9.8 \\
05\end{array}$ & $\begin{array}{l}1.9 \\
12\end{array}$ & & $\begin{array}{l}<0 . \\
000 \\
1 \\
\end{array}$ & $\begin{array}{l}7.3 \\
95\end{array}$ & $\begin{array}{l}1 . \\
44 \\
1 \\
\end{array}$ & & $\begin{array}{l}<0 . \\
000 \\
1 \\
\end{array}$ \\
\hline
\end{tabular}




\begin{tabular}{|c|c|c|c|c|c|c|c|c|c|c|c|c|c|c|c|c|c|}
\hline IMFc & $\begin{array}{l}- \\
7.8 \\
69 \mathrm{x} \\
10^{-8}\end{array}$ & $\begin{array}{l}0 . \\
00 \\
0\end{array}$ & -0.606 & $\begin{array}{l}0.00 \\
4\end{array}$ & $\begin{array}{l}- \\
1.4 \\
64 \mathrm{x} \\
10^{-8}\end{array}$ & $\begin{array}{l}0 . \\
00 \\
0\end{array}$ & -0.014 & $\begin{array}{l}0.9 \\
33\end{array}$ & & $\begin{array}{l}- \\
1.1 \\
54 \\
x \\
10 \\
8\end{array}$ & $\begin{array}{l}0.0 \\
00\end{array}$ & -0.227 & $\begin{array}{l}0.2 \\
01\end{array}$ & $\begin{array}{l}- \\
5.8 \\
35 \mathrm{x} \\
10^{-8}\end{array}$ & $\begin{array}{l}0 . \\
00 \\
0\end{array}$ & -0.395 & $\begin{array}{l}0.0 \\
31\end{array}$ \\
\hline \multirow[t]{2}{*}{$\begin{array}{l}\text { IBRD } \\
\text { L }\end{array}$} & $\begin{array}{l}2.7 \\
79 x \\
10^{-9}\end{array}$ & $\begin{array}{l}0 . \\
00 \\
0\end{array}$ & 0.521 & $\begin{array}{l}0.01 \\
3\end{array}$ & $\begin{array}{l}4.1 \\
05 \mathrm{x} \\
10^{-9}\end{array}$ & $\begin{array}{l}0 . \\
00 \\
0\end{array}$ & 0.240 & $\begin{array}{l}0.1 \\
47\end{array}$ & & $\begin{array}{l}- \\
2.6 \\
96 \\
x \\
10 \\
10\end{array}$ & $\begin{array}{l}0.0 \\
00\end{array}$ & -0.181 & $\begin{array}{l}0.3 \\
06\end{array}$ & $\begin{array}{l}- \\
2.0 \\
50 \mathrm{x} \\
10^{-} \\
10\end{array}$ & $\begin{array}{l}0 . \\
00 \\
0\end{array}$ & -0.068 & $\begin{array}{l}0.7 \\
00\end{array}$ \\
\hline & \multicolumn{4}{|c|}{$\begin{array}{l}\text { Model 6: Dependent } \\
\text { Variable GINI } \\
\text { R-squared:0.177 } \\
\text { ANOVA: F=645; } p=0.558\end{array}$} & \multicolumn{4}{|c|}{$\begin{array}{l}\text { Model 6: Dependent } \\
\text { Variable GINI } \\
\text { R-squared:0.107 } \\
\text { ANOVA: } F=0.301 ; p=0.753\end{array}$} & $\begin{array}{l}\text { Model 6: Dependent } \\
\text { Variable GINI } \\
\text { Not applicable (no IMFc } \\
\text { data for South Korea) }\end{array}$ & \multicolumn{4}{|c|}{$\begin{array}{l}\text { Model 6: Dependent } \\
\text { Variable GINI } \\
\text { Not Applicable. only one } \\
\text { year of data for GINI } \\
\text { coefficient }\end{array}$} & \multicolumn{4}{|c|}{$\begin{array}{l}\text { Model 6: Dependent } \\
\text { Variable GINI } \\
\text { R-squared:0.432; Adjusted } \\
\text { R-square=0.204 } \\
\text { ANOVA: } F=1.898 ; p=0.244\end{array}$} \\
\hline $\begin{array}{l}\text { (Con } \\
\text { stant } \\
\text { ) } \\
\end{array}$ & $\begin{array}{l}43 . \\
520\end{array}$ & $\begin{array}{l}0 . \\
94 \\
5 \\
\end{array}$ & & $\begin{array}{l}<0.0 \\
001\end{array}$ & $\begin{array}{l}44 . \\
685\end{array}$ & $\begin{array}{l}3 . \\
17 \\
2 \\
\end{array}$ & & $\begin{array}{l}<0 . \\
000 \\
1 \\
\end{array}$ & & & & & & $\begin{array}{l}43 . \\
032\end{array}$ & $\begin{array}{l}1 . \\
33 \\
8 \\
\end{array}$ & & $\begin{array}{l}<0 . \\
000 \\
1\end{array}$ \\
\hline IMFc & $\begin{array}{l}- \\
1.8 \\
93 \mathrm{x} \\
10^{-8} \\
\end{array}$ & $\begin{array}{l}0 . \\
00 \\
0\end{array}$ & -0.546 & $\begin{array}{l}0.32 \\
2\end{array}$ & $\begin{array}{l}1.5 \\
34 \mathrm{x} \\
10^{-7}\end{array}$ & $\begin{array}{l}0 . \\
00 \\
0\end{array}$ & 0.235 & $\begin{array}{l}0.6 \\
03\end{array}$ & & & & & & $\begin{array}{l}- \\
3.8 \\
84 \mathrm{x} \\
10^{-8}\end{array}$ & $\begin{array}{l}0 . \\
00 \\
0\end{array}$ & -0.636 & $\begin{array}{l}0.1 \\
73\end{array}$ \\
\hline $\begin{array}{l}\text { IBRD } \\
\text { L }\end{array}$ & $\begin{array}{l}3.4 \\
29 \mathrm{x} \\
10^{-} \\
10\end{array}$ & $\begin{array}{l}0 . \\
00 \\
0\end{array}$ & 0.241 & $\begin{array}{l}0.65 \\
2\end{array}$ & $\begin{array}{l}2.2 \\
30 \mathrm{x} \\
10^{-9}\end{array}$ & $\begin{array}{l}0 . \\
00 \\
0\end{array}$ & 0.214 & $\begin{array}{l}0.6 \\
35\end{array}$ & & & & & & $\begin{array}{l}8.9 \\
60 \mathrm{x} \\
10^{-} \\
10\end{array}$ & $\begin{array}{l}0 . \\
00 \\
0\end{array}$ & 0.724 & $\begin{array}{l}0.1 \\
31\end{array}$ \\
\hline
\end{tabular}




\section{Epilogue}

In the present paper, the researchers presented data examining the initial research question whether the IMF and the World Bank cause financial instability in the countries they intervene. Examples were drawn from interventions in the Russian Federation and East Asia. Linear regression models were performed that shows when IMF charges increased there was a decrease in Annual GDP growth and annual industrial value. Although graphically there seems to be an increase in inflation, unemployment and plummeting of the GDP per capita when the IMF intervenes, this is not shown in the linear regression models.

This study has certain limitations which need to be mentioned. Initially, the role of the IMF in other crisis situations wasn't discussed, such as the Mexican Tequila crisis in 1994, widely known as the Mexican peso crisis, caused by the sudden devaluation of the Mexican peso in December 1994. Also, the policy measures of the IMF have not been discussed in the matter of the European Debt crisis and especially the case of Greece. Although there hasn't been a comprehensive study on the effects of the IMF in Greek economic crisis, many scholars have noted the inadequacy of the conditionality and the Washington consensus in dealing with it (Arghyrou and Tsoukalas, 2011; Manolopoulos, 2011).

However, a different approach in international monetary policies is the recent Seoul Development Consensus, which seems to address many of the weaknesses of the Washington consensus. The Seoul Development Consensus for Shared Growth is a set of principles and guidelines set up to assist the G20 nations and other global actors in working collaboratively with less developed countries in order to boost their economic growth and to achieve the UN's Millennium Development Goals. It was endorsed by the leaders of G20 nations at the 2010 G-20 Seoul summit, with a multi year action plan drafted for the delivery of tangible results. In contrast with the older Washington
Consensus, the Seoul Consensus allows a larger role for state intervention. Rather than seeking to impose a uniform "top down" solution, it postulates that solutions should be tailored to the requirements of individual developing nations, with the developing countries themselves taking the lead in designing packages of reforms and policies best suited to their needs.

The Washington Consensus as originally defined was a set of ten key principles. The new Consensus is based on six core principles and has nine 'key pillars'. The six core principles of the Seoul consensus are (Lee and Mathews, 2010):

- Focus on Economic Growth The G20 suggest that economic growth is closely linked with low income countries' (LICs) ability to achieve the Millennium Development Goals. They state that measures to promote inclusive, sustainable and resilient growth should take precedence over business as usual.

- Global Development Partnership. LICs should be treated as equal partners, with national ownership for their own development. Partnerships should be transparent and accountable.

- Global or Regional Systemic Issues. The G20 should prioritise regional or systemic issues where their collective action is best placed to deliver beneficial changes.

- Private Sector Participation. The G20 recognise the importance of private actors in contributing to growth and suggest that policies should be business friendly.

- Complementarity. The G20 will try to avoid duplicating the efforts of other global actors, focussing their efforts on areas where they have a comparative advantage.

- Outcome Orientation. The G20 will focus on tangible practical measures to address significant problems.

In conclusion, we focus on the negative effects of the policies implemented by the IMF and the WB to resolve financial crises (Abbott et al., 2010). These negative-for- 
growth approaches include the promotion of liberalization/stabilization/privatization measures which, in both cases of East Asia and Russia, didn't suite entirely with regional economic conditions. There are arguments which support that international policies of the IMF and the WB are affected by preferences of their most powerful members, by their own bureaucratic motives and by politics within countries with whom they work-especially that of the US government (Woods, 2006, p. 179); however, our aim is not to condemn the existence of the IMF and the WB. Their contribution to international financial stability is still needed but under some necessary reform, which will be less conditional and more considerate of regional, financial and social issues (Minton-Beddoes, 1995). The role of other international organizations, such as the G20 and the recent Seoul Development consensus seems emergingly important.

\section{Endnotes}

i. Schinasi (2004) and Gadanecz and Jayaram (2009) give a fine list of definitions. Schinasi's (2004, p. 8) most broad definition is: 'Financial stability can be thought of in terms of the financial system's ability: (a) to facilitate both an efficient allocation of economic resources and the effectiveness of other economic processes, (b) to assess, price, allocate, and manage financial risks, and (c) to maintain its ability to perform these key functions primarily through selfcorrective mechanisms'. See Table A.1, Appendix for Financial Soundness Indicators (Djebbar, 2009; Gadanecz and Jayaram, 2009) and Schinasi (2004, pp. 13-16) for a full list of definitions.

ii. See Table A.2, Appendix for a detailed description of the IMF history from its establishment date (1945) until today.

iii. See Table A.3, Appendix for a full set of objectives of the IMF.

iv. See Figure A.1, Appendix for the phases of the IMF programs and Table A.4,
Appendix for the nature of its support packages towards countries in need.

v. The WB group consists of five specialized institutions. See Table A.5, Appendix for details.

vi. See Table A.6, Appendix for a detailed description of the IMF's criticisms.

vii. We will refer to the Russian Federation as Russia throughout the text.

viii. See Gould-Davies and Woods (1999) for a thorough discussion on the reasons of such a choice of the IMF.

ix. See Figure A.2 for a map of East Asian countries. Figure 4 shows that in Malaysia, Indonesia, Thailand, and Korea GDP per capita increased at least four-fold during 1960-1996. Moreover, the benefits of economic growth were shared throughout the population. Incomes of the poorest $20 \%$ of the population grew just as fast as average incomes, and poverty rates fell significantly in each country (Radelet et al., 1998).

x. Currency speculation involves borrowing in a currency that the borrower expects to be devalued; if he borrows 1000 baht, but then the baht becomes worth $40 \%$ less than its worth at the time of the loan, he profits - because it takes less real money to pay back the loan (Driscoll and Clark, 2003, p. 176).

xi. Seven high-profile bankruptcies of Korean conglomerates took place, such as Hanbo Steel and Kia Motors.

xii. In South Korea, unemployment rose from approximately 3 to $10 \%$, while in Indonesia, poverty rates rose from 11 $\%$ before the crisis to $40-60 \%$; and GDP declined by $15 \%$ in one year. Quality of life also came down with the advent of malnutrition and suicides (Weisbrot et al., 2001).

xiii. In Indonesia a series of financial deregulation packages led to 
tremendous expansion in the banking sector: the number of private banks (including foreign and joint venture banks) nearly tripled from 74 in 1988 to 206 six years later. Thailand introduced in 1992 the Bangkok International Banking Facility (BIBF) to compete with Singapore and Hong Kong, allowing for very rapid growth in the number of financial institutions that could borrow and lend in foreign currencies, both on- and offshore. In Korea, financial market reforms in the mid-1990s similarly opened the door to greatly expanded banking activity and increased the access of domestic banks to short-term international loans (Radelet et al., 1998).

xiv. The Asian governments were generally not running budget deficits but budget surpluses. In Thailand, the government was running such large surpluses that it was actually starving the economy of much-needed investments in education and infrastructure, both essential to economic growth. And the East Asian nations already had tight monetary policies as well: inflation was low and falling (Figure 7) (Stiglitz, 2002; 2003).

$\mathrm{xv}$. Certain key domestic factors were: failure to dampen overhearing pressures that had become increasingly evident in Thailand and many other countries in the region and were manifested in large external deficits and property and stock market bubbles and lax prudential rules and financial oversight, which led to sharp deterioration in the quality of banks' loan portfolios (Radelet et al., 1998, p. 61; Berg, 1999).

xvi. Thailand was asked to take fiscal contractionary adjustments equal to approximately $2.6 \%$ of GDP (from a deficit of $1.6 \%$ of GDP in fiscal year 1996-97 to a surplus of 1\% of GDP in fiscal year 1997-98) ; Indonesia was required to take fiscal contractionary actions equal to $1 \%$ of GDP in fiscal year 1997-98 and 2 percent of GDP in fiscal year 1998-99; and Korea was asked to take adjustment measures equal to $1.5 \%$ of GDP in 1998-99 (Radelet et al., 1998).

\section{References}

Abbott, P., Andersen, T. B. \& Tarp, F. (2010). "IMF and Economic Reform in Developing Countries," Quarterly Review of Economics and Finance, 50 (1), 17-26.

Anderson, J., Barnard, G., Laursen, T., Roaf, J., Robinson, D., Rutkowska, I., Spatafora, N., McDonald, C. \& Santos, A. (2000). "Russian Federation: Selcted Issues," IMF Staff Country Report 00/150. International Monetary Fund, Washington, DC. Available at:

http://www.imf.org/external/pubs/ft/wp /2004/wp04187.pdf (Accessed)

Arghyrou, M. G. \& Tsoukalas, J. D. (2011). "The Greek Debt Crisis: Likely Causes, Mechanics and Outcomes," World Economy, 34 (2), 173-191.

Barro, R. J. (2001). "Economic Growth in East Asia before and after the Financial Crisis," National Bureau of Economic Research Working Paper Series, No. 8330.

Berg, A. (1999). 'The Asia Crisis: Cause, Policy Responses, and Outcomes,' IMF Working Paper, 99/138.

Brau, E. \& McDonald, I. (eds.) (2009). Successes of the International Monetary Fund: Untold Stories of Cooperation at Work, Palgrave Macmillan, Hampshire.

Dawson, J., Mukoyama, M., Choi, S. C. \& Larke, R. (eds.) (2003). The Internationalisation of Retailing in Asia RoutledgeCurzon, New York.

Dawson, T. C. (2003). 'The IMF's Role in Asia: Part of the Problem or Part of Teh Solution?,' in Driscoll, W. and Clark, J. (eds) Globalization and the Poor: Exploitation or Equalizer? International Debate Education Association, New York, 219-227.

Djebbar, M. (2009). 'Predicting Financial Crises: Myth and Reality,' Paper presented at the PIEEM/Universite de Sétif, Algeria, 20-21 October. Available at: 
http://www.iefpedia.com/english/wpcontent/uploads/2010/03/PredictingFinancial-Crises-Myth-and-Reality-

Mahfoud-

DJEBBAR.pdf (Accessed: 26 February 2011).

Driscoll, W. \& Clark, J. (eds.) (2003). Globalization and the Poor: Exploitation or Equalizer? International Debate Education Association, New York.

Fischer, S. (2003).'The Asian Crisis: A View from the IMF,' in Driscoll, W. and Clark, J. (eds) Globalization and the poor: exploitation or equalizer? International Debate Education Association, New York, 206-218.

Foreign-\&-Commonwealth-Office-UK. (2010) Russia Country Profile. Available at: http://www.fco.gov.uk/en/travel-andliving-abroad/travel-advice-bycountry/country-profile/europe/russia (Retrieved: 5 March 2010).

Gadanecz, B. \& Jayaram, K. (2009). "Measures of Financial Stability - a Review," IFC Bulletin, 31, 365-380.

Gaidar, Y. (1997). "The IMF and Russia," The American Economic Review, 87 (2), 1316.

Garten, J. E. (1999). "Lessons for the Next Financial Crisis," Foreign Affairs, 78 (2), 7692.

Gilman, M. (2010). No Precedent, No Plan: Inside Russia's 1998 Default, MIT Press, Cambridge, Mass.

Gould-Davies, N. \& Woods, N. (1999). "Russia and the IMF," International Affairs, 75 (1), 1-21.

Haggard, S. (2003). "The Asian Financial Crisis of 1997-99," in Driscoll, W. and Clark, J. (eds) Globalization and the Poor: Exploitation or Equalizer? International Debate Education Association, New York, 178-194.

Head, J. W. (2004). 'Seven Deadly Sins: An Assessment of Criticisms Directed at the
International Monetary Fund,' University of Kansas Law Review, 52 (3), 521-582.

Lee, K. \& Mathews, J. A. (2010). "From Washington Consensus to BeST Consensus for world development," Asian-Pacific Economic Literature, 24 (1), 86-103.

Manolopoulos, J. (2011). Greece's 'Odious' Debt: The Looting of the Hellenic Republic by the Euro, the Political Elite and the Investment Community, Anthem Press, London.

Meltzer, A. H. (2006). "Reviving the Bank and Fund," Review of International Organizations, 1 (1), 49-59.

Minton-Beddoes, Z. (1995). "Why the IMF Needs Reform," Foreign Affairs, 74 (3), 123133.

Mussa, M. \& Savastano, M. (1999). "The IMF Approach to Economic Stabilization," NBER Macroeconomics Annual, 14, 79-122.

Peet, R. (2009). 'Unholy Trinity: the IMF, World Bank and WTO,' Zed Books, London.

Polak, J. J. \& Gwin, C.(1994). The World Bank and the International Monetary Fund: A Changing Relationship, in Kapur, D., Lewis, J.P. and Webb, R. (eds) The World Bank: Its First Half Century. Brookings Institution Press, Washington, DC, 473-521.

Przeworski, A. \& Vreeland, J. R. (2000). "The Effect of IMF Programs on Economic Growth," Journal of Development Economics, 62 (2), 385-422.

Radelet, S. \& Sachs, J. D. (1998). 'The East Asian Financial Crisis: Diagnosis, Remedies, Prospects,' Brookings Papers on Economic Activity, 1998 (1), 1-90.

Reserve-Bank-of-Australia. (2005). "Financial Stability Review, March 2005," Reserve Bank of Australia, London.

Schinasi, G. J. (2004). "Defining Financial Stability," IMF Working Paper, 04/187. 
Soros, G. (2009). The Crash of 2008 and What it Means: the New Paradigm for Financial Markets, PublicAffairs, New York

Stiglitz, J. (2003). "What I learned at World Economic Crisis," in Driscoll, W. and Clark, J. (eds) Globalization and the Poor: Exploitation or Equalizer? International Debate Education Association, New York, 195-205.

Stiglitz, J. E. (2002). Globalization and Its Discontents, Penguin, London.

Weisbrot, M., Baker, D., Naiman, R. \& Neta, G. (2001). "Growth May be Good for the Poor-But are IMF and World Bank Policies Good for Growth," CEPR Briefing paper.

Woods, N. (2006). The Globalizers: the IMF, the World Bank, and their Borrowers, Cornell University Press, Ithaca.

World-Bank. (2000). Annual Report, World Bank, Washington, DC.

World-Bank. (2011) World Bank Indicators. Available at: http://www.worldbank.org (Retrieved: 20 October 2011)

Yokoi-Arai, M. (2002). Financial Stability Issues: the Case of East Asia, Kluwer Law International, London

\section{Further Reading}

Acharya, V. V. \& Richardson, M. (eds). (2009). Restoring Financial Stability: How to Repair a Failed System, Wiley, New Jersey.

Archibugi, D. (2008). The Global Commonwealth of Citizens: Toward Cosmopolitan Democracy, Princeton University Press, Princeton, NJ:

Blackmon, P. (2008). "Reflection, Evaluation, Integration: Rethinking Poverty through the Eyes of the International Monetary Fund and the World Bank," International Studies Review 10 (2), 179202.
Buira, A. (2003). Challenges to the World Bank and IMF: Developing Country Perspectives, Anthem Press, London.

Conway, P. (2006). "The International Monetary Fund in a Time of Crisis: A Review of Stanley Fischer's IMF Essays from a Time of Crisis: The International Financial System, Stabilization, and Development," Journal of Economic Literature 44 (1), 115-144.

Danaher, K. (2001). 10 Reasons to abolish the IMF \& World Bank, Seven Stories Press, New York.

Driscoll, W. \& Clark, J. (eds.) (2003). Globalization and the Poor: Exploitation or Equalizer? International Debate Education Association, New York.

Feldstein, M. (1998). "Refocusing the IMF," Foreign Affairs 77 (2), 20-33.

Kumar, A. (ed.) (2003). World Bank Literature, University of Minnesota Press, Minneapolis.

Mason, E. S. \& Asher, R. E. (1973) The World Bank since Bretton Woods: the origins, policies, operations, and impact of the International Bank for Reconstruction and Development and the other, Brookings Institution, Washington, DC.

Onimode, B. (ed.). (1991). The IMF, the World Bank and the African Debt: The Social and Political Impact, Zed Books, London.

Orphanides, A. \& Wieland, V. (2000). "Efficient Monetary Policy Design near Price Stability," Journal of the Japanese and International Economies 14 (4), 327-365.

Schneider, B. (ed.). (2003). The Road to International Financial Stability, Palgrave Macmillan, New York.

Shihata, I. F. I. (2000). The World Bank Inspection Panel: In Practice, 2nd edn., Oxford University Press, New York 
Tirole, J. (2002). Financial Crises, Liquidity, and the International Monetary System, Princeton University Press, Princeton, NJ.

Wade, R. (1998). "The Asian Debt-anddevelopment Crisis of 1997-?: Causes and Consequences," World Development 26 (8), 1535-1553.

Woods, N. (2000). The Political Economy of Globalization, Macmillan Press, London. 
Appendix

Figures

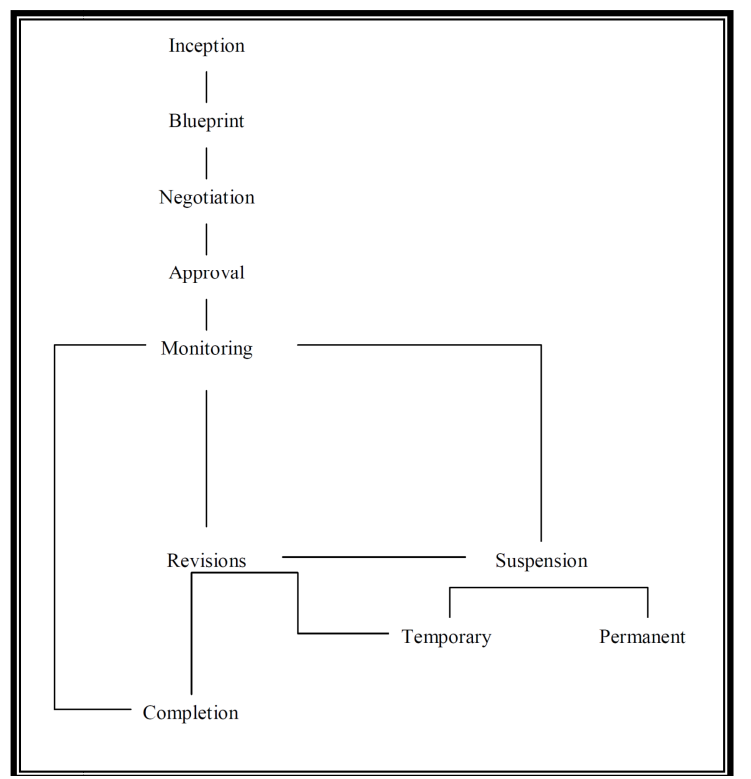

Fig. A.1. Phases of IMF Programs "Source: Mussa and Savastano (1999, p. 86)".

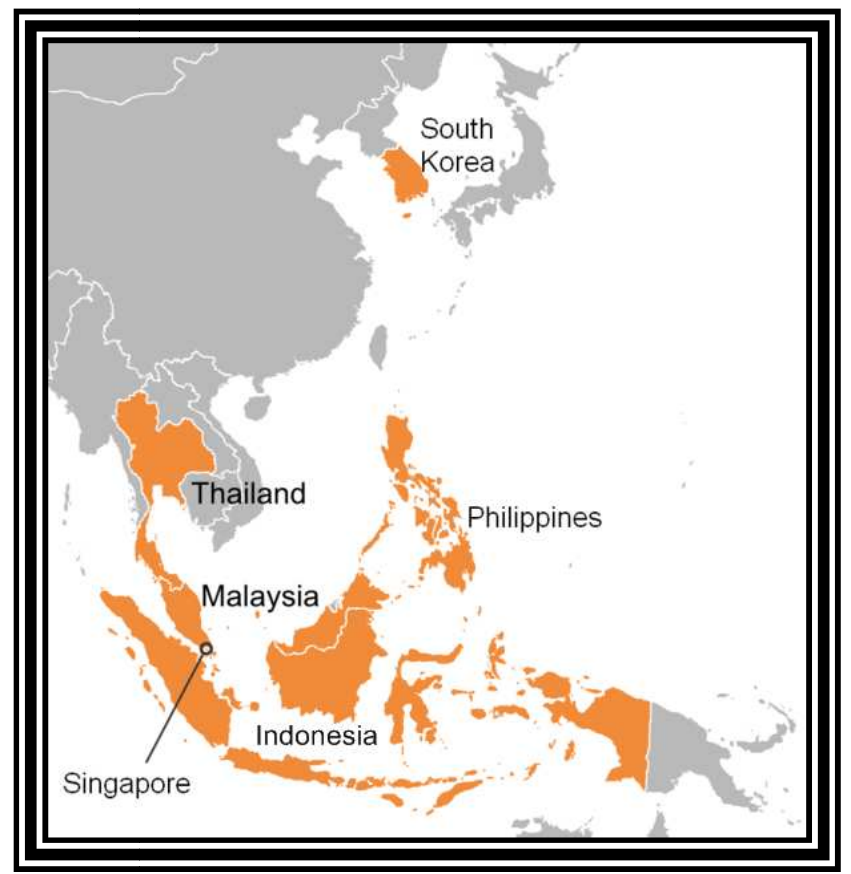

Fig. A.2. Map of East Asian Countries Hit by the Financial Crisis of 2 July 1997 Source: $\underline{\text { http://en.wikipedia.org/wiki/1997 Asian financial crisis }}$ 
Table A.1. Financial Soundness Indicators

\begin{tabular}{|c|c|c|}
\hline & Number & Indicator \\
\hline \multicolumn{3}{|l|}{$\begin{array}{l}\text { CORE SET } \\
\text { Denosit-takers }\end{array}$} \\
\hline Deposit-takers & & \\
\hline \multirow[t]{3}{*}{ Capital adequacy } & 1 & Regulatory capital to risk-weighted assets \\
\hline & 2 & Regulatory Tier 1 capital to risk-weighted assets \\
\hline & 3 & Non-performing loans net of provisions to capital \\
\hline \multirow[t]{2}{*}{ Asset quality } & 4 & Non-performing loans to total gross loans \\
\hline & 5 & Sectoral distribution of loans to total loans \\
\hline \multirow[t]{4}{*}{ Earnings and profitability } & 6 & Return on assets \\
\hline & 7 & Return on equity \\
\hline & 8 & Interest margin to gross income \\
\hline & 9 & Non-interest expenses to gross income \\
\hline \multirow{2}{*}{ Liquidity } & 10 & Liquid assets to total assets (liquid asset ratioa) \\
\hline & 11 & Liquid assets to short-term liabilities \\
\hline Sensitivity to market risk & 12 & Net open position in foreign exchange to capital \\
\hline \multicolumn{3}{|l|}{ ENCOURAGED SET } \\
\hline \multirow[t]{13}{*}{ Deposit-takers } & 13 & Capital to assets \\
\hline & 14 & Large exposures to capital \\
\hline & 15 & Geographical distribution of loans to total loans \\
\hline & 16 & Gross asset position in fi nancial derivatives to capital \\
\hline & 17 & Gross liability position in fi nancial derivatives to capital \\
\hline & 18 & Trading income to total income \\
\hline & 19 & Personnel expenses to non-interest expenses \\
\hline & 20 & Spread between reference lending and deposit rates \\
\hline & 21 & Spread between highest and lowest interbank rate \\
\hline & 22 & Customer deposits to total (non-interbank) loans \\
\hline & 23 & Foreign-currency-denominated loans to total loans \\
\hline & 24 & Foreign-currency-denominated liabilities to total liabilities \\
\hline & 25 & Net open position in equities to capital \\
\hline \multirow[t]{2}{*}{ Other financial corporations } & 26 & Assets to total financial system assets \\
\hline & 27 & Assets to GDP \\
\hline \multirow{5}{*}{$\begin{array}{l}\text { Non-financial } \\
\text { corporate sector }\end{array}$} & 28 & Total debt to equity \\
\hline & 29 & Return on equity \\
\hline & 30 & Earnings to interest and principal expenses \\
\hline & 31 & Net foreign exchange exposure to equity \\
\hline & 32 & Number of applications for protection from creditors \\
\hline \multirow[t]{2}{*}{ Householders } & 33 & Household debt to GDP \\
\hline & 34 & Household debt service and principal payments to income \\
\hline \multirow[t]{2}{*}{ Market liquidity } & 35 & Average bid-ask spread in the securities market \\
\hline & 36 & Average daily turnover ratio in the securities market \\
\hline \multirow[t]{3}{*}{ Real estate markets } & 37 & Real estate prices \\
\hline & 38 & Residential real estate loans to total loans \\
\hline & 39 & Commercial real estate loans to total loans \\
\hline
\end{tabular}

Source: Reserve Bank of Australia (2005, p. 51), Djebbar (2009), Gadanecz and Jayaram (2009, pp. 367-369) 
Table A.2. The History of the International Monetary Fund

\begin{tabular}{|c|c|}
\hline Dates & Events \\
\hline 1930 & $\begin{array}{l}\text { During the Great Depression, countries attempted to shore up their failing } \\
\text { economies by sharply raising barriers to foreign trade, devaluing their } \\
\text { currencies to compete against each other for export markets, and curtailing } \\
\text { their citizens' freedom to hold foreign exchange. These attempts proved to } \\
\text { be self-defeating. World trade declined sharply (see chart below), and } \\
\text { employment and living standards plummeted in many countries. }\end{array}$ \\
\hline 1-22 July 1944 & $\begin{array}{l}\text { The Articles of Agreement of both the IMF and the World Bank are drawn } \\
\text { up at the International Monetary and Financial Conference, Bretton Woods, } \\
\text { New Hampshire, USA. }\end{array}$ \\
\hline July 1945 & $\begin{array}{l}\text { The IMF was conceived, when representatives of } 45 \text { countries meeting in } \\
\text { the town of Bretton Woods, New Hampshire, in the northeastern United } \\
\text { States, agreed on a framework for international economic cooperation, to } \\
\text { be established after the Second World War. They believed that such a } \\
\text { framework was necessary to avoid a repetition of the disastrous economic } \\
\text { policies that had contributed to the Great Depression. }\end{array}$ \\
\hline 27 December 1945 & $\begin{array}{l}\text { The IMF came into formal existence, when its first } 29 \text { member countries } \\
\text { signed its Articles of Agreement. }\end{array}$ \\
\hline 1 March 1947 & IMF began formally its operations \\
\hline 1949 & $\begin{array}{l}\text { France is the first country to draw funds from the IMF, followed in the same } \\
\text { year by the Netherlands, Mexico and the United Kingdom. }\end{array}$ \\
\hline 1952 & $\begin{array}{l}\text { Members on procedures for annual consultations on exchange restrictions } \\
\text { and for Stand-By Agreements, drawing and charges. Belgium is the first } \\
\text { country to enter into a Stand-By Agreement with the IMF but makes no } \\
\text { drawing until } 1957 \text {. }\end{array}$ \\
\hline 1962 & $\begin{array}{l}\text { To secure that it has enough cash on hand should an industrial country } \\
\text { need a loan to cover a balance of payments, the IMF introduces the General } \\
\text { Agreements to Borrow. These agreements enable it to supplement its } \\
\text { financial resources by borrowing from the governments of a group of } \\
\text { member countries. }\end{array}$ \\
\hline 1969 & $\begin{array}{l}\text { In response to the threat of a shortage of international liquidity, the Articles } \\
\text { of Agreement are emended to create Special Drawing Rights }\end{array}$ \\
\hline 1971 & $\begin{array}{l}\text { The United States suspends the convertibility of the dollar into gold, ending } \\
\text { the par value system of fixed exchange rates, under which countries defined } \\
\text { their currencies in terms of U.S. dollars or gold and were obligated to get } \\
\text { the IMF approval to change the "par value" by more than } 10 \text { percent. }\end{array}$ \\
\hline 1971-1974 & $\begin{array}{l}\text { On December } 23,1973 \text {, oil-exporting countries announce a steep increase } \\
\text { in crude oil prices to take effect on January } 1,1974 \text {. To help oil importers } \\
\text { deal with anticipated current account deficits and inflation in the face of } \\
\text { higher oil prices, the IMF sets up the first of two oil facilities. }\end{array}$ \\
\hline 1975 & $\begin{array}{l}\text { The Extended Fund Facility is established in } 1974 \text { to provide medium-term } \\
\text { assistance to developing country members that need several years to } \\
\text { address the economic weaknesses leading to their balance of payments } \\
\text { problems. In 1975, Kenya is the first country to benefit an Extended Fund } \\
\text { Facility arrangement. }\end{array}$ \\
\hline 1982 & $\begin{array}{l}\text { The oil shocks of the } 1970 \text { s, which forced many oil-importing countries to } \\
\text { borrow from commercial banks, and the interest rate increases in } \\
\text { industrial countries trying to control inflation lead to an international debt } \\
\text { crisis. Throughout the } 1980 \text { s, the IMF plays a central role in helping resolve } \\
\text { the crisis. }\end{array}$ \\
\hline 1986 & $\begin{array}{l}\text { The Structural Adjustment Facility, one of the predecessors of the Poverty } \\
\text { Reduction and Growth Facility, is established, enabling the IMF to lend at }\end{array}$ \\
\hline
\end{tabular}




\begin{tabular}{|c|c|}
\hline Dates & Events \\
\hline & below-market rates to poor countries. \\
\hline 1987 & $\begin{array}{l}\text { To increase the resources available for concessional lending to developing } \\
\text { member countries, the IMF introduces the Enhanced Structural Adjustment } \\
\text { Facility. }\end{array}$ \\
\hline 1992 & $\begin{array}{l}\text { The Russian Federation and } 13 \text { of the } 14 \text { other states of the former Soviet } \\
\text { Union join the IMF. }\end{array}$ \\
\hline 1995 & $\begin{array}{l}\text { An } \$ 18 \text { billion loan is negotiated for Mexico to help the country recover } \\
\text { from a capital account crisis. }\end{array}$ \\
\hline 1996 & $\begin{array}{l}\text { The IMF and the World Bank jointly launch the Heavily Indebted Poor } \\
\text { Countries (HIPC) Initiative with the aim of reducing the external debt of the } \\
\text { world's poorest and heavily indebted countries to sustainable levels in a } \\
\text { reasonably short period. }\end{array}$ \\
\hline $1997-1998$ & $\begin{array}{l}\text { Financial crisis erupts in Thailand, followed by crises in other Southeast } \\
\text { Asian countries. The IMF provides loans totaling more than } \$ 36 \text { billion to } \\
\text { Indonesia, Korea, and Thailand in support of stabilization policies and } \\
\text { structural reforms. The crisis spills over to countries in other areas, such as } \\
\text { Russia, whose currency is devalued. Russia defaults on its debt. }\end{array}$ \\
\hline 1999 & $\begin{array}{l}\text { The IMF replaces the Enhanced Structural Adjustment Facility with the } \\
\text { Poverty Reduction and Growth Facility, which gives explicit attention to } \\
\text { poverty reduction, and the HIPC Initiative is enhanced to provide faster, } \\
\text { broader, and deeper debt relief. }\end{array}$ \\
\hline 2000 & $\begin{array}{l}\text { The UN Millennium Development Goals are agreed by world leaders at the } \\
\text { UN Millennium Summit. }\end{array}$ \\
\hline 2001 & $\begin{array}{l}\text { Argentina suffers a financial crisis and a deep recession, defaults on its } \\
\text { debt, and is forced to abandon its currency board pegging the peso to the } \\
\text { U.S. dollar. }\end{array}$ \\
\hline 2005 & $\begin{array}{l}\text { The G-8 launch the Multilateral Debt Relief Initiative, and the IMF agrees to } \\
\text { forgive } 100 \text { percent of the } \$ 3.3 \text { billion debt awed to it by } 19 \text { of the world's } \\
\text { poorest countries. }\end{array}$ \\
\hline 2007 & $\begin{array}{l}\text { The growing pace and reach of globalization begin to change the world's } \\
\text { economic order, bringing forward new countries as global trading, } \\
\text { industrial, and commodity powers. The IMF brings to change too, boosting } \\
\text { the influence in the institution of the major emerging economies. }\end{array}$ \\
\hline
\end{tabular}

Source: http://www.imf.org 
Table A.3. The Objectives of the IMF

1. To promote international monetary co-operation through a permanent institution which provides the machinery for consultation and collaboration on international monetary problems

2. To facilitate the expansion and balanced growth of international trade, and to contribute thereby to the promotion and maintenance of high levels of employment and real income and to the development of the productive resources of all members as primary objectives of economic policy.

3. To promote exchange stability, to maintain orderly exchange arrangements among members, and to avoid competitive exchange depreciation.

4. To assist in the establishment of a multilateral system of payments in respect of current transactions between members and in the elimination of foreign exchange restrictions which hamper the growth of the world trade.

5. To give confidence to members by making the general resources of the Fund temporarily available to them under adequate safeguards, thus providing them with the opportunity to correct maladjustments in their balance of payments without resorting to measures destructive of national or international prosperity.

6. In accordance with the above, to shorten the duration and lessen the degree of disequilibrium in the international balances of payments of members.

Source: http://www.imf.org

Table A.4. The IMF's Loans under a Variety of 'Arrangements' and 'Facilities'

Stand-by Arrangements assure member countries that they can draw up to specified amount, usually over twelve to eighteen months, to deal with short-term balance of payments problems.

The Extended Fund Facility provides assurance that member countries can draw up to a specified amount, usually over three to four years, to make structural economic changes that the IMF thinks will improve balance of payments.

The Poverty Reduction and Growth Facility (replacing the Enhanced Structural Adjustment Facility in 1999) provides low-interest loans to the lowest-income member countries facing protracted balance of payments problems, with the cost to borrowers subsidized by funds raised through past sales of IMF-owned gold, together with loans and grants from richer member countries.

The Supplemental Reserve Facility provides additional short-term loans at higher interest rates to member countries experiencing exceptional balance of payments difficulties because of sudden loss of market confidence reflected in capital outflows.

Contingent Credit Lines provide precautionary IMF financing on a short-term basis when countries are faced by a sudden loss of market confidence because of contagion from difficulties in other countries.

Emergency Assistance helps countries coping with balance of payments problems arising from sudden and unforeseeable natural disasters or, since 1995, emergency conditions stemming from military conflicts

Source: Peet (2009, p. 73) 
Table A.5. The Five Specialized Institutions that the World Bank Consists of

\begin{tabular}{l}
\hline 1. The International Bank for Reconstruction and Development (IBRD) makes development loans, \\
guarantees loans and offers analytical and advisory services. The IBRD borrows at low interest \\
rates by selling bonds in private capital markets in First World countries and makes near-market \\
interest loans to 'credit-worthy countries' in the Third World and elsewhere. It has made about \\
$\$ 360$ illion in loans over its lifetime and currently lends $\$ 10.5$ billion a year for some ninety new \\
operations in thirty-six countries. \\
2. The International Development Association (IDA) gives loans to countries are 'usually not \\
creditworthy' in international financial markets. IDA loans carry no interest, but a 0.75 percent \\
administrative charge is made annually. The IDA, averaging $\$ 6$ billion a year in leading to the \\
poorest countries, is funded from member government's national budgets. \\
3. The International Finance Corporation (IFC) is the largest multilateral source of loan and equity \\
financing for private sector projects in the developing world. \\
4. The Multilateral Investment Guarantee Agency (MIGA) provides investment insurance. \\
5. The International Center for Settlement of Investment Disputes (ICSID) facilitates the settlement of \\
investment disputes between governments and foreign investors
\end{tabular}

Source: http://www.worldbank.org

Table A.6. Criticisms of the IMF

\begin{tabular}{|c|c|}
\hline \multicolumn{2}{|c|}{ Criticisms of the IMF's policies and operations } \\
\hline Criticism 1 & $\begin{array}{l}\text { Bad medicine. The IMF prescribes economic and financial policies that fail to } \\
\text { cure, and that indeed often make sicker, its borrowing member countries and the } \\
\text { entire world economy. }\end{array}$ \\
\hline Criticism 2 & $\begin{array}{l}\text { Distributional and social injustice. The economic and financial policies that } \\
\text { the IMF insists on create distributional inequities and ignore the social aspects of } \\
\text { a country's well-being. }\end{array}$ \\
\hline Criticism 3 & $\begin{array}{l}\text { Trampling of national sovereignty. In imposing conditionality on its loans, the } \\
\text { IMF tramples on national sovereignty-not just in economics but increasingly in } \\
\text { other areas of state autonomy. }\end{array}$ \\
\hline \multicolumn{2}{|c|}{ Criticisms of the character, control, and reach of the IMF } \\
\hline Criticism 4 & $\begin{array}{l}\text { Secrecy and opaqueness. The IMF is a closed, non-transparent organization } \\
\text { that operates in secret, despite its insistence on transparency in the } \\
\text { governments of its members. }\end{array}$ \\
\hline Criticism 5 & $\begin{array}{l}\text { The democracy deficit. Controlled by a handful of rich countries, the IMP is an } \\
\text { unaccountable autocracy in which the people most affected by its operations } \\
\text { have no chance to participate. }\end{array}$ \\
\hline Criticism 6 & $\begin{array}{l}\text { Mission creep. As both a legal and a practical matter, the IMF has overstepped } \\
\text { its authority and its competence in providing bailouts and adopting policies on a } \\
\text { proliferation of topics. }\end{array}$ \\
\hline Criticism 7 & $\begin{array}{l}\text { Asymmetry in obligations. The rich member countries who insist that the poor } \\
\text { borrowing member countries follow certain policies are under no real pressure } \\
\text { to follow those policies themselves. }\end{array}$ \\
\hline
\end{tabular}

Source: Head (2004, pp. 531-532) 